\title{
亚胺及其类似物的催化不对称炔基化反应新进展
}

\author{
周淑芯温凯歌曾兴平* \\ (江西师范大学化学化工学院 功能有机小分子教育部重点实验室和江西省绿色化学重点实验室 南昌 330022)
}

\begin{abstract}
摘要 手性炔丙胺是天然产物和药物活性分子不对称全合成中常用的关键中间体，亚胺及其类似物的不对称炔基化反 应可以为该砌块提供高效高对映选择性的合成路径; 此外通过合理的底物和反应设计，亚胺的不对称炔基化反应还能 作为一系列串联反应的起点, 来合成多种结构新颖的含氮杂环化合物. 因此, 亚胺及其类似物的高效高对映选择性炔 基化反应得到合成化学家们持续关注. 按照底物类型, 主要分为醛亚胺的不对称炔基化和酮亚胺的不对称炔基化两大 部分, 介绍了亚胺及其类似物的不对称炔基化反应在过去十年中的研究进展. 对这些反应的机理、优势与不足之处以 及该反应在合成中的应用进行简要讨论, 从而为拓展该反应在合成中的应用提供一些有益参考和借鉴.
\end{abstract}

关键词 手性炔丙胺; 不对称炔基化; 醛亚胺; 酮亚胺; 含氮杂环化合物

\section{Recent Progress in Catalytic Asymmetric Alkynylation of Imines}

\author{
Zhou, Shurui Wen, Kaige Zeng, Xingping* \\ (Key Laboratory of Small Fuctional Organic Molecule, Ministry of Education and Jiangxi Key Laboratory of Green \\ Chemistry, College of Chemistry and Chemical Engineering, Jiangxi Normal University, Nanchang 330022)
}

\begin{abstract}
Chiral propargyl amines are key intermediates in the asymmetric total synthesis of natural products and bioactive compounds. The asymmetric alkynylation of imine and its analogues can provide a highly efficient and enantioselective synthetic route for these chiral building blocks. In addition, through rational substrate and reaction design, the asymmetric alkynylation of imines can be used as the starting point of a series of cascade reactions to synthesize a variety of novel nitrogen-heterocyclic compounds. Therefore, highly efficient and enantioselective alkynylation of imines and their analogues has attracted the continuous attention of synthetic chemists. According to the types of substrate, the research progress in asymmetric alkynylation of imines and their analogues over the past decade is introduced, which is divided into two parts: asymmetric alkynylation of aldimines and asymmetric alkynylation of ketoimines. The reaction mechanism and their advantages and disadvantages, together their synthetic applications will be briefly introduced, hoping to provide some useful inspiration for expanding the application of this reaction in synthesis.

Keywords chiral propargyl amine; asymmetric alkynylation; aldimine; ketoimine; nitrogen-heterocyclic compound
\end{abstract}

末端炔在手性催化剂的作用下与亚胺及其类似物 的不对称加成反应是有机合成中重要反应之一(Scheme $1)^{[1]}$. 首先, 该反应所生成的手性炔丙胺产物是重要的 合成砌块, 可以发生诸如氢化、分子内氢转移、分子内 亲核加成反应 $(\mathrm{a} \sim \mathrm{c})$ 等转化来合成在天然产物和生物活 性分子中广泛分布的手性 $\alpha$-烷基胺、烯丙基胺及不饱和 环状化合物等; 其次, 通过合理的设计, 亚胺及其类似 物的不对称炔基化反应还能作为诸多串联反应 $(\mathrm{d} \sim \mathrm{e})$ 的 起点来合成结构新颖的氮杂环状化合物. 因此, 发展末 端炔对亚胺及其类似物的高效高对映选择性加成反应,
对促进相关天然产物的全合成研究和新型药物活性分 子的设计开发具有重要的意义, 该反应也因此得到了化 学家们的持续关注.

亚胺及其类似物的不对称炔基化反应在过去的几 十年得到了深入研究, 发展出了许多高效高选择性的催 化剂, 相关反应也在天然产物分子的全合成中得到了广 泛应用，该反应也成为了许多综述论文关注的热点 ${ }^{[2]}$. 但经调研文献发现，最新的专注于介绍亚胺及其类似物 不对称炔基化反应的综述是由 Pedro 和侯士聪课题 组 ${ }^{[2 b-2 c]}$ 分别于 2009 和 2010 年所发表.

\footnotetext{
* Corresponding author. E-mail: 005173@jxnu.edu.cn

Received July 16, 2020; August 11, 2020; published online September 8, 2020.

Project supported by the Open Project Program of Key Laboratory of Functional Small Organic Molecule, Ministry of Education, Jiangxi Normal University (No. KLFS-KF-201603) and the Foundation of Jiangxi Educational Committee (No. 170223).

江西师范大学功能有机小分子教育部重点实验室开放基金(No. KLFS-KF-201603)和江西省教育厅(No. 170223)资助项目.
} 


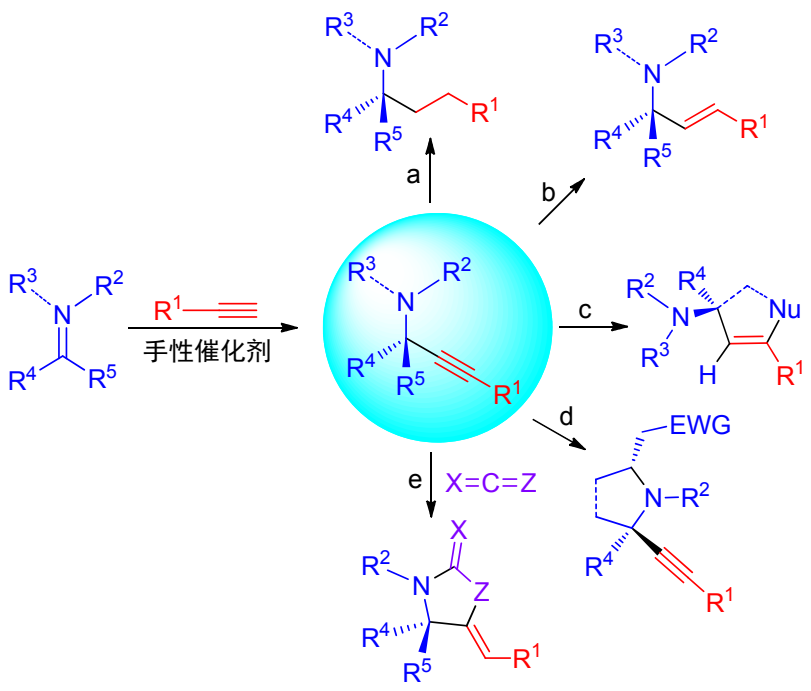

图式 1 亚胺的不对称炔基化反应

Scheme 1 Asymmetric alkylation of imines

在过去的十年中, 经过化学家们的不解努力, 又有 许多新颖高效的催化体系被报道, 其在合成中的应用范 围也在不断的拓展中. 因此, 我们认为对亚胺及其类似 物不对称炔基化反应研究的最新进展进行综述, 让读者 对该反应的最新研究成果有一个较为全面的了解, 从而 为拓展该反应在合成中的应用提供一些有益参考和借 鉴, 对相关领域的发展具有促进意义. 按照底物类型, 本综述主要分为醛亚胺和酮亚胺的不对称炔基化两大 部分, 对反应的机理、优势与不足以及在合成中的应用 进行简要讨论.

\section{1 醛亚胺的不对称炔基化反应}

由于醛亚胺其中的一边是氢原子取代, 亲核试剂对 其进攻时的空间位阻相对较小, 因此醛亚胺不对称炔基 化反应的活性相对较高, 也因此的得到了较酮亚胺不对 称炔基化更为广泛的研究. 经过多年发展, 醛亚胺不对 称炔基化反应已不仅仅是一种制备手性炔丙胺的高效 合成方法, 更是新配体和新催化剂展示其在不对称合成 应用潜力的一个重要平台.

\section{1 非环状醛亚胺的不对称炔基化反应}

2010 年, 王锐课题组 ${ }^{[3]}$ 设计合成一系列手性氨基醇 类三齿配体并尝试该类配体在亚胺的不对称炔基化反 应中催化效果(Scheme 2). 经过结构优化, 发现当使用 $35 \mathrm{~mol} \%$ 2-噻吩基取代的氨基醇 1 作为配体时, 末端炔 烃 3 对二苯磷酰基亚胺 $\mathbf{2}$ 的不对称加成反应可以取得 $75 \% \sim 89 \%$ 的产率和高达 $96 \%$ 的对映选择性. 反应对一 系列芳环上含有不同电性和位置取代基的亚胺都展示 了很好的兼容性, 但仅尝试了芳基和杂芳基末端炔底 物.

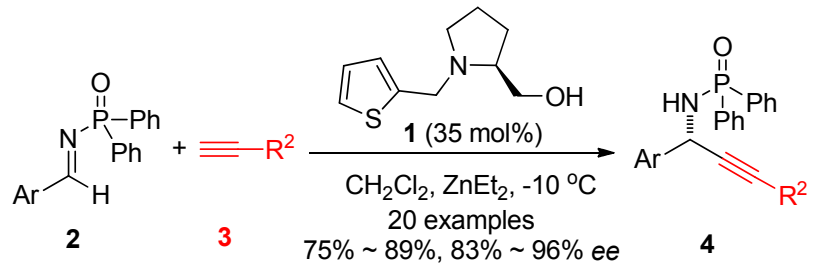

Selected examples

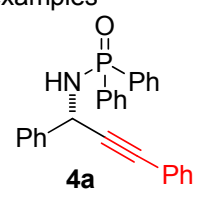

$(83 \%, 91 \%$ ee)

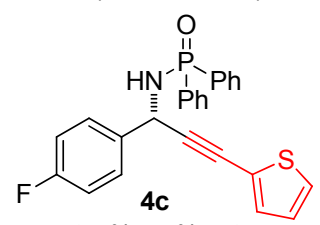

(79\%, 95\% ee)

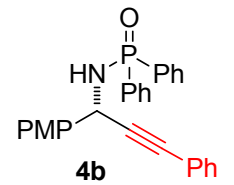

$(89 \%, 91 \%$ ee $)$

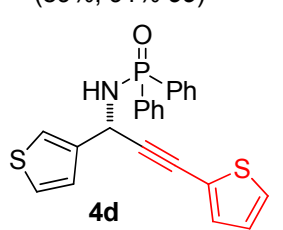

$(84 \%, 96 \%$ ee $)$
图式 2 氨基醇类三齿配体参与催化的不对称炔基化反应 Scheme 2 Tridentate ligand catalyzed asymmetric alkynylation

2012 年, Pedro 等 ${ }^{[4]}$ 研究发现, 使用 3,3'-双取代的手 性联䒺酚作为配体也能实现上述反应(Scheme 3). 在对 配体的结构进行优化的过程中, 作者发现常见的大位阻 3,3'-二芳基联菜酚类配体并未能实现最佳的立体选择性
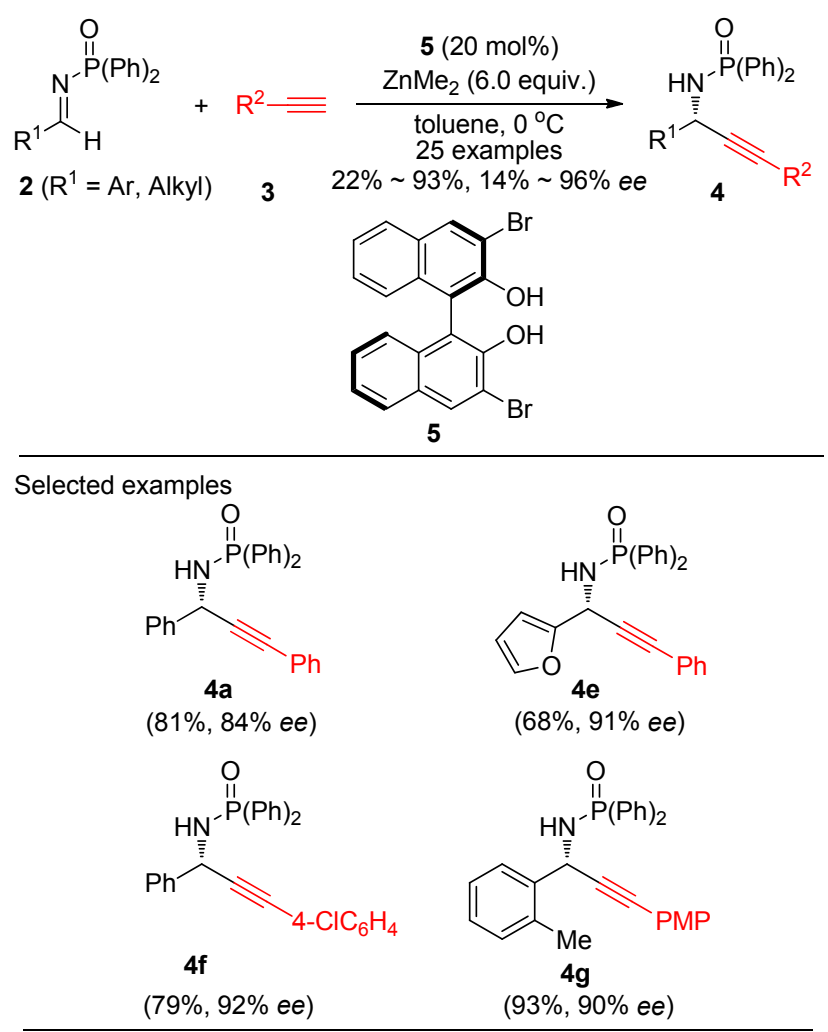

图式 3 3,3'-二溴联菜酚配体参与催化的不对称炔基化反应 Scheme 3 Enantioselective alkylation catalyzed by 3,3'-dibromo-BINOL complex 
控制; 相反, 使用简单的 3,3'-二溴联萗酚(5)时，反应可 取得最高 $93 \%$ 的产率和高达 $96 \%$ 的对映选择性. 在标准 条件下, 芳环上带有不同取代基的芳基和杂芳基亚胺和 芳基炔均能够被兼容, 并取得良好到优秀的产率和对映 选择性; 但是该反应对烷基亚胺和烷基末端炔的兼容性 不佳, 目标产物仅能取得 $15 \%$ 左右的 $e e$ 值.

2012 年, 马军安课题组 ${ }^{[5]}$ 利用手性联荎酚和二甲 基锌的组合实现了末端炔对 $N$-Ts 醛亚胺的不对称加成 反应(Scheme 4). 在 $20 \mathrm{~mol} \%$ 的大位阻 3,3,-二芳基联萗 酚 6 和 2 equiv. $\mathrm{Me}_{2} \mathrm{Zn}$ 的存在下，一系列烷基、芳基和 硅基取代的末端 1,3-二炔 8 对芳基酫亚胺的加成反应均 可取得良好到优秀的产率和对映选择性(Scheme 4a) ${ }^{[5 a] \text {; }}$ 烷基和三氟甲基醛亚胺的反应则仅能取得中等的 $e e$ 值. 此后, 该课题组 ${ }^{[5 b]}$ 利用上述催化体系进一步实现了烯 炔基化反应(Scheme 4b). 芳基和杂芳基取代的亚胺、芳 基和烷基末端烯炔都能很好地适用于该反应并以良好 到优秀的 $e e$ 值得到炔丙胺产物 $\mathbf{1 1}$, 但烷基醛亚胺的反 应结果依旧不甚理想.

(a)

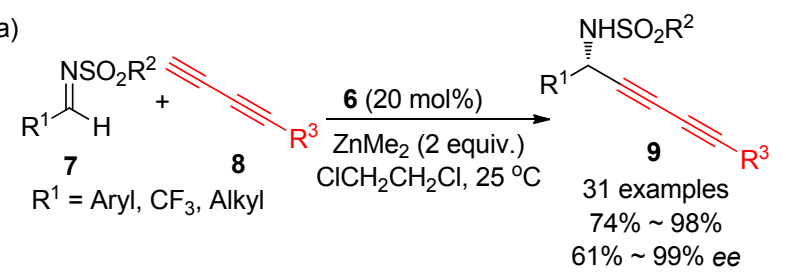

(b)

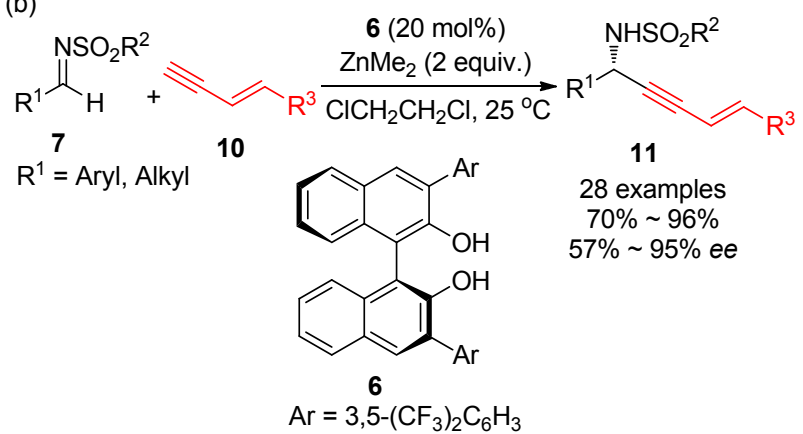

图式 $4 N$-磺酰基醛亚胺的不对称炔基化反应

Scheme 4 Enantioselective alkylation of $N$-sulfonyl aldimines

由于使用预先制备的亚胺来进行反应需要先对亚 胺进行分离提纯, 从而使得操作相对更为繁琐; 此外, 由于许多亚胺化合物对水较为敏感, 在分离过程中容易 发生分解，进一步增加了亚胺提纯操作的难度. 鉴于此, 合成化学家们发展了一系列原位生成亚胺的不对称炔 基化反应, 从对水和空气相对稳定的亚胺前体出发, 在 反应体系中原位生成亚胺并直接进行不对称炔基化反 应，这样可以避免亚胺中间体的分离提纯等繁琐操作， 因而可以大大提高反应的实用性.

Pedro 课题组 ${ }^{[6]}$ 于 2012 年报道了一例以 $\alpha$-砜基胺 12
作为亚胺前体化合物的不对称炔基化反应(Scheme 5). 在强碱 $\mathrm{Et}_{2} \mathrm{Zn}$ 的作用下, 12 可以现场生成亚胺, 后者在 3,3'-二芳基联荎酚配体 $\mathbf{6}$ 与 $\mathrm{Et}_{2} \mathrm{Zn}$ 络合物的催化作用下, 与末端炔发生加成反应即可以 $33 \% \sim 94 \%$ 的产率和高达 95\%的对映选择性得到相应的炔丙胺产物 13. 除了芳基 和杂芳基亚胺，该反应对脂肪族亚胺也展现了不错的催 化活性，相应的目标产物也能取得中等的对映选择性.
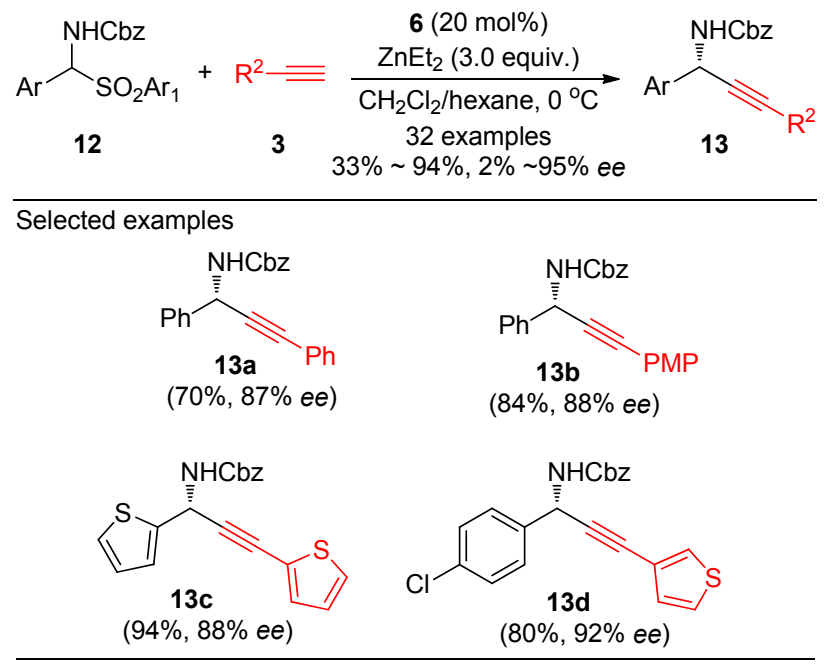

图式 5 原位生成亚胺的不对称炔基化反应

Scheme 5 Enantioselective alkynylation of in situ generated aldimines

此后, 刘否课题组 ${ }^{[7]}$ 研究发现 $N$-芳基甘氨酸酯可以 被 $\mathrm{O}_{2}$ 氧化现场生成亚胺来发生后续的不对称炔基化反 应，形式上为脱氢偶联反应(Scheme 6). 使用手性 1-氨 基-2-䒢满醇衍生的 PyBOX 配体 14 和 $\mathrm{Cu}(\mathrm{OTf})_{2}$ 的络合 物作为催化剂, 一系列 $N$-芳基甘氨酸酯 15 均能顺利被 氧化从而实现与不同的芳基末端炔 3 反应，并以最高 $80 \%$ 的产率和 $80 \%$ 的 $e e$ 值得到相应的炔丙胺产物 16. 值 得一提的是，该反应也能实现烷基末端炔参与的不对称 炔基化反应，相应的产物可取得高达 $87 \%$ 的对映选择 性. 作者还尝试了 $N$-甲基和 $N$-乙酰基取代的甘氨酸酯 底物，但是反应未能发生.

除了简单的加成反应得到手性炔丙胺产物，醛亚胺 的不对称加成反应还被引入多组分串联反应中来高效 制备一系列手性氮杂环化合物(Scheme 7) ${ }^{[8]}$. 例如, Toste 等 ${ }^{[9 a}$ ]报道了亚胺、末端炔和对甲苯磺酰基异氰酸酯之间 的三组分串联反应来制备结构新颖的 2-亚氨基四氢噁 唑衍生物(Scheme 7,a). 亚胺 18 和末端炔 3 首先在带有 脲基团的手性单磷配体 17 衍生的阳离子金络合物的催 化下发生不对称加成反应得到手性炔丙胺中间体 $\mathbf{A}$, 接 着与酰基异氭酸酯 19 发生加成反应的得到炔丙基脲中 间体 $\mathbf{B}$, 再经进一步的分子内氧氢化反应即能以中等到 

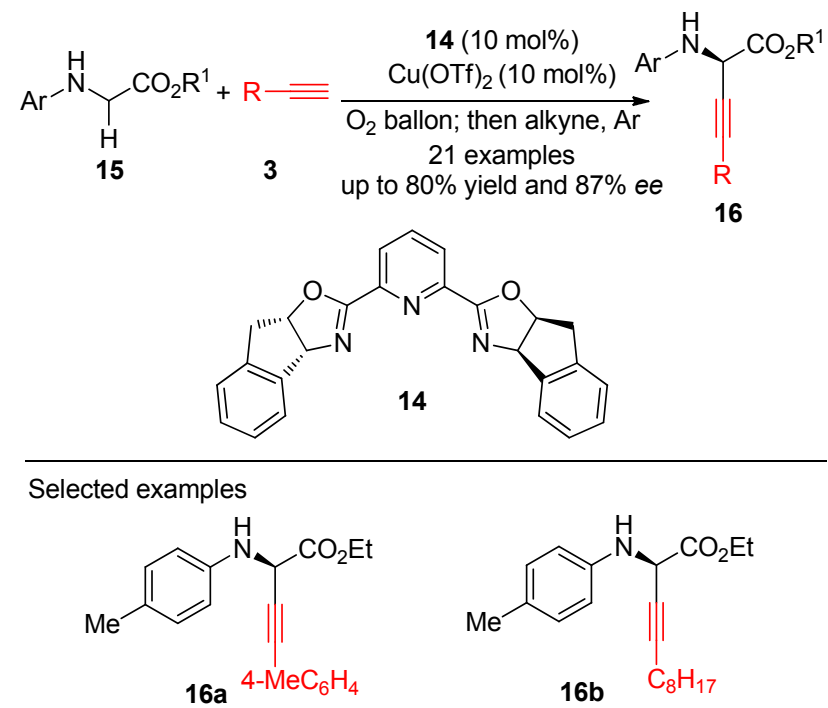

(78\%, 80\% ee)

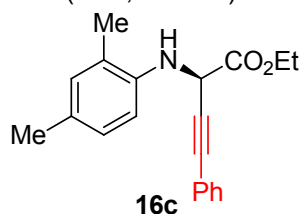

$(67 \%, 74 \%$ ee $)$

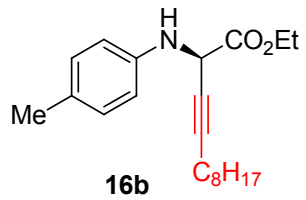

$(65 \%, 87 \%$ ee)

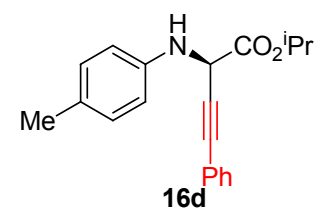

$(80 \%, 82 \%$ ee $)$

图式 $6 \mathrm{~N}$-芳基甘氨酸酯与末端炔的不对称脱氢偶联反应

Scheme 6 Enantioselective cross-dehydrogenative coupling of $\mathrm{N}$-aryl glycine esters with terminal alkynes

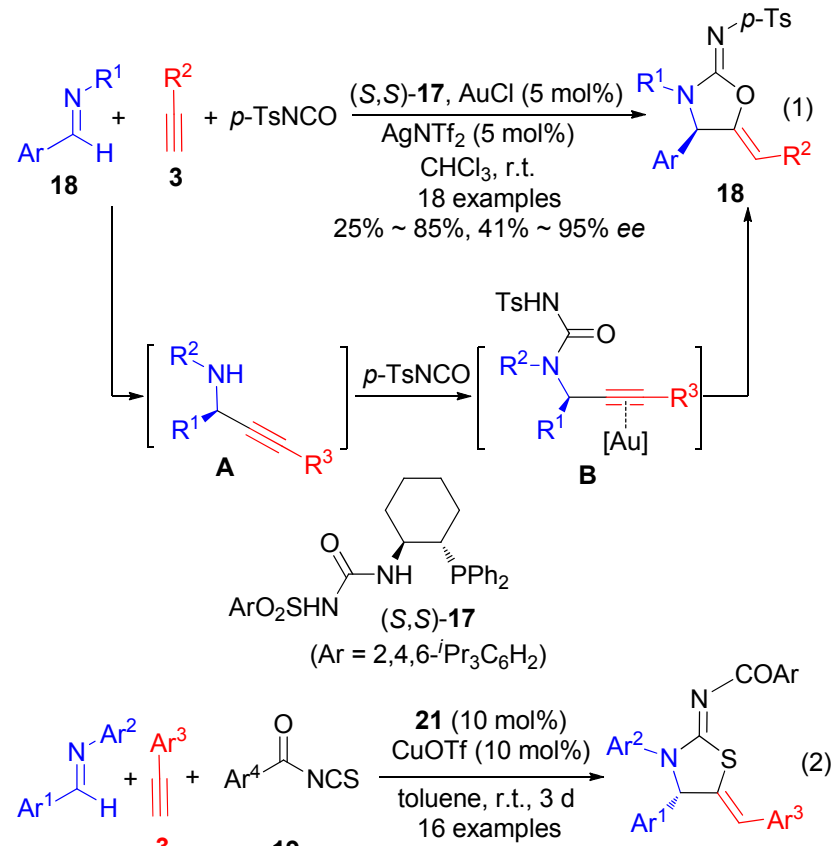

$1975 \% \sim 95 \%, 60 \% \sim 99 \%$ ee 20

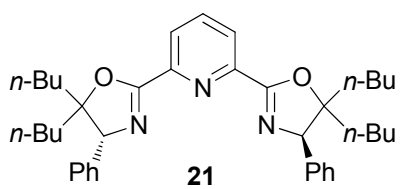

图式 7 基于不对称炔基化衍生的串联反应合成

Scheme 7 Asymmetric alkynylation derived cascade reactions

优秀的 $e e$ 值得到相应的手性四氢噁唑衍生物 20. 由于 部分反应在分子内环化反应的区域选择性不佳，使得最 终产率大多仅有中等水平. 此后, Dethe 等 ${ }^{[0 b]}$ 于 2015 年 报道了一例不对称炔基化/硫氢化串联反应来合成 2-亚 氨基四氢噻唑(Scheme 7,b). 用 PyBOX 和 CuOTf 络合 物作为催化剂, 使得环化反应能够区域专一地进行，最 终的 2-亚氨基四氢噻唑 23 取得 75\% 95\%的产率和 $60 \% \sim 99 \%$ 的 $e e$ 值.

\section{2 环状醛亚胺的不对称炔基化反应}

与非环状亚胺的不对称炔基化反应不同的是，环状 亚胺的不对称炔基化反应可以合成一系列手性炔丙基 取代的氮杂环状化合物; 由于氮杂环状化合物也广泛分 布于天然产物和生物活性分子中，因此该类反应也得到 了化学家的持续关注.

2011 年, Maruoka 等 ${ }^{[10]}$ 使用手性一价铜络合物作为 催化剂，实现了末端炔 $\mathbf{3}$ 对环状偶氮甲碱亚胺 $\mathbf{2 2}$ 的不对 称加成反应，制备了手性 1-炔基四氢异喹啉衍生物 24 (Scheme 8). 经过一系列条件优化，他们最终发现使用 苯基 PyBOX 作为手性配体、 $\mathrm{CuOAc}$ 作为金属盐，反应 可取得最佳的结果; 在 $0{ }^{\circ} \mathrm{C}$ 下，一系列不同取代的环状 偶氮甲碱亚胺和芳基末端炔的反应均能顺利进行并取 得最高 94\%的ee 值. 此外，烷基和三甲基硅基取代的末 端炔参与反应也能取得非常好的结果 $(\mathbf{2 4 c} \sim 24 \mathrm{~d})$.

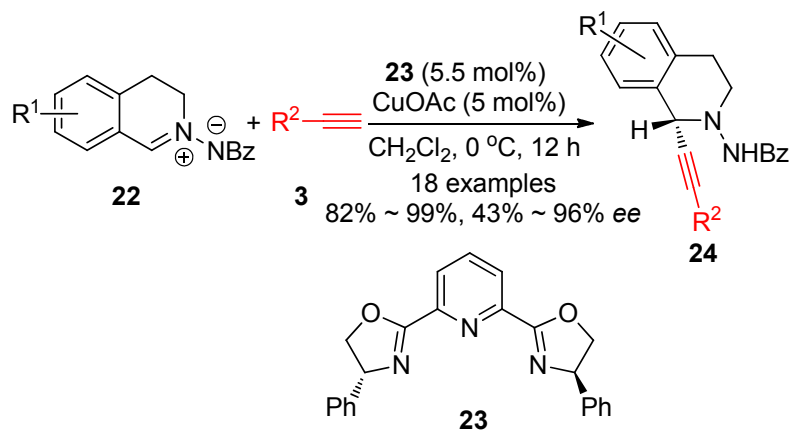

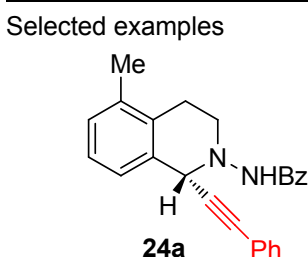

$(99 \%, 91 \%$ ee $)$

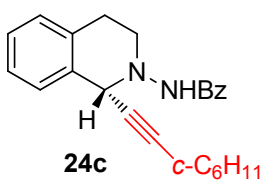

$(82 \%, 89 \%$ ee $)$

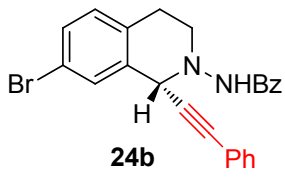

$(96 \%, 94 \%$ ee)

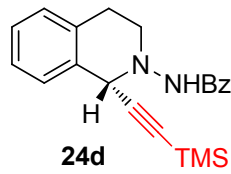

$(89 \%, 96 \%$ ee $)$
图式 8 环状偶氮甲碱亚胺的不对称加成反应

Scheme 8 Asymmetric alkynylation of $C, N$-cyclic azomethine imines 
此后, Aponick 等 ${ }^{[11]}$ 利用他们所发展的 StackPhos 作 为手性配体, 实现了一系列喹啉衍生物与氯甲酸乙酯和 末端炔的不对称偶联反应来合成 2-炔基二氢喹啉衍生 物(Scheme 9). 喹啉衍生物 26 首先在二异丙基乙基胺 (DIPEA)的作用下发生酰基化反应得到活性更高的喹啉 鎓盐中间体 $\mathbf{A}$ ，该中间体接着与手性炔基铜络合物发生 加成反应即可以高达 $86 \%$ 的产率和优秀的对映选择性 得到一系列 2-炔基二氢喹啉衍生物 27. 该反应的一个 非常突出的优势在于能够兼容一系列链状的末端炔底 物, 使其在合成中具有广阔的应用前景. 以上述反应所 得到的产物作为关键中间体, 经过 $\mathrm{Pd} / \mathrm{C}$ 催化氢化和后 续的 $\mathrm{LiAlH}_{4}$ 还原可以实现四氢喹啉类生物碱 $(+)$-Galipinine, (+)-Cuspareine 和(-)-Angustureine 的 不对称全合成.
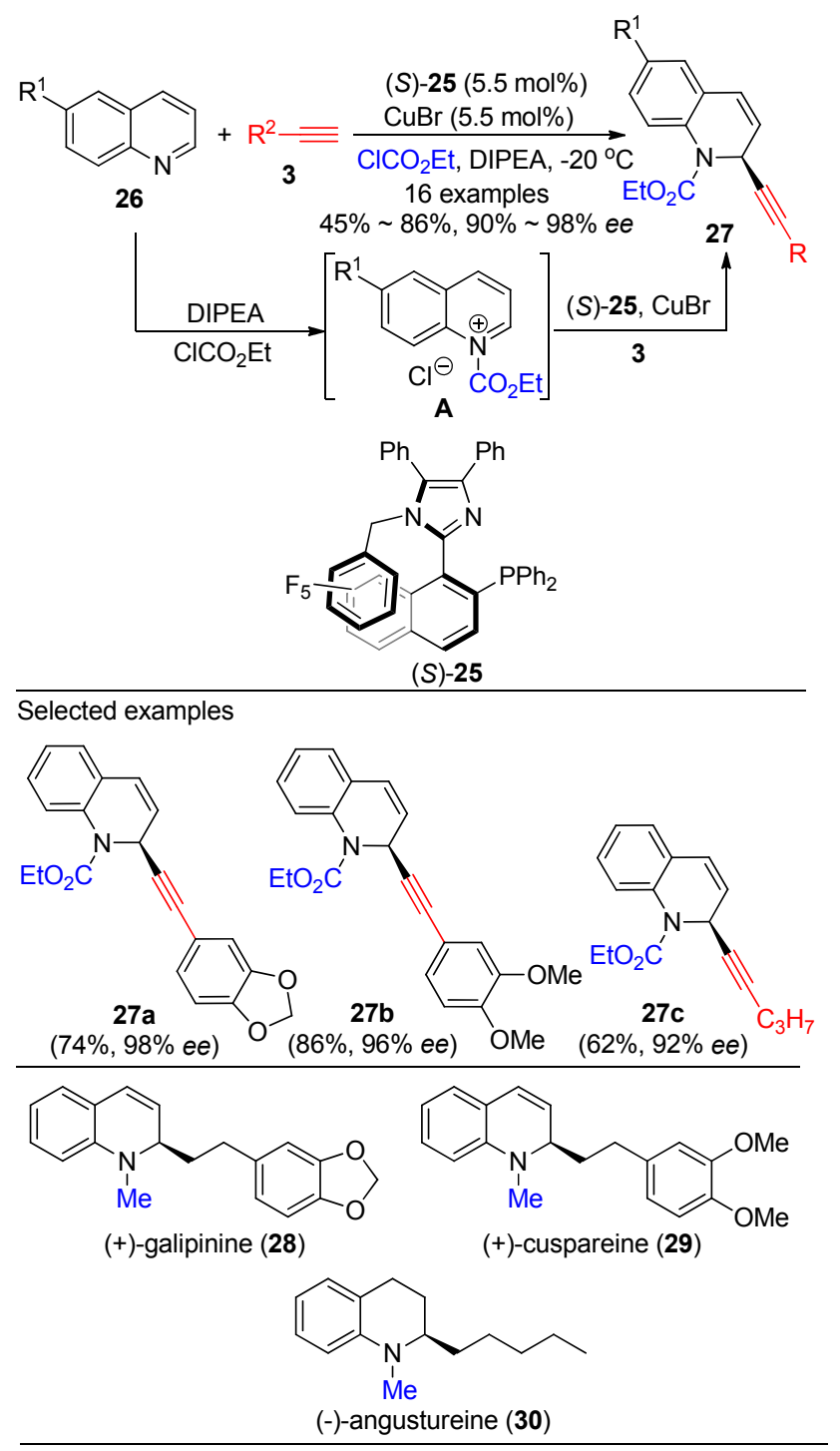

图式 9 铜催化喹啉衍生物的不对称炔基化反应

Scheme 9 Asymmetric copper-catalyzed quinoline alkynylation

最近, 关正辉等 ${ }^{[12]}$ 使用苯基 PyBOX 衍生的一价铜
络合物作为催化剂, 外消旋手性磷酸作为添加剂, 实现 了一系列异喹啉鎓盐 32 的不对称炔基化反应来制备 1炔基 1,2-二氢异喹啉衍生物 33 (Scheme 10). 该反应对 一系列芳环上带有不同取代基的芳基末端炔展现了较 好的兼容性，反应最高能取得 $96 \%$ 的对映选择性. 作者 发现，添加外消旋或者手性的磷酸可以提高反应的产 率，但不影响对映选择性，预示着磷酸并不参与反应的 手性决定步骤.
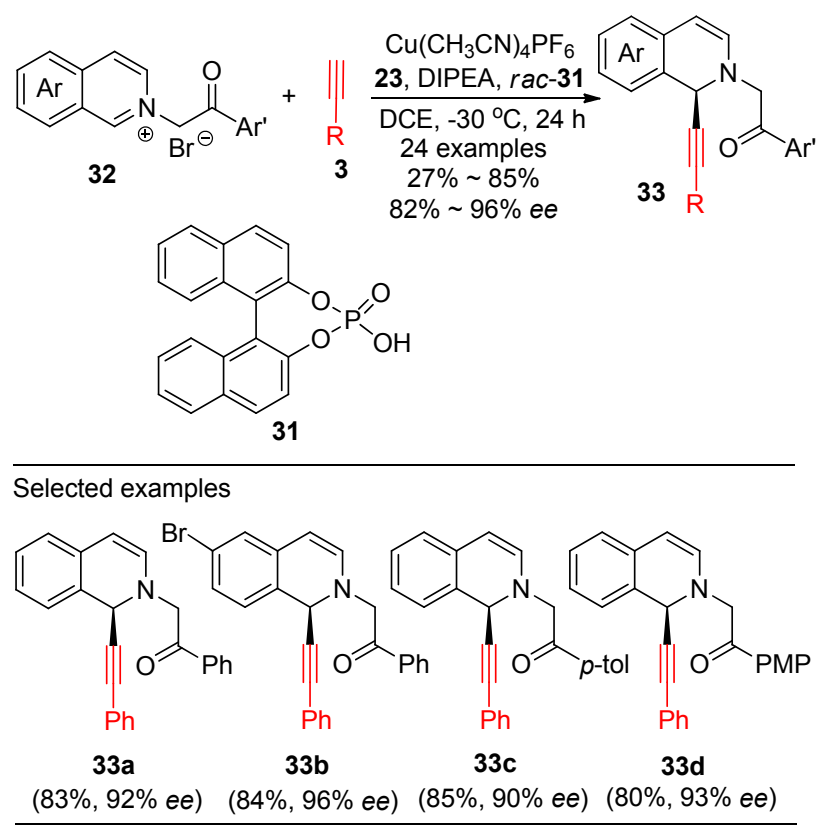

图式 10 异喹啉的不对称去芳构化炔基化反应 Scheme 10 Asymmetric dearomative alkynylation of isoquinolines

除了喹啉和异喹啉衍生物, 化学家们也尝试了其他 类型环状亚胺的不对称炔基化反应，例如汪游清等 ${ }^{[13]}$ 在 2014 年报道了七元环状亚胺 $\mathbf{3 5}$ 的不对称炔基化反应 (Scheme 11). 在最佳条件下，使用大位阻的手性磷酸 34 衍生的银盐作为催化剂，一系列芳基末端炔、共轭烯炔 和 1,3-二炔均能和 35 顺利发生加成反应并以最高 $96 \%$ 的产率和高达 $99 \%$ 的 $e e$ 值得到目标产物; 此外, 该文作 者也尝试了烷基炔类底物, 但是反应的活性和对映选择 性均有所下降.

接着在 2015 年, Pedro 课题组 ${ }^{[14]}$ 使用 $(R)$-VAPOL 衍 生的锌络合物作为手性催化剂实现了一系列末端炔对 苯并六元环状磺酰亚胺 38 的不对称加成反应(Scheme 12). 芳基、杂芳基取代的末端炔在反应中展示了较高的 反应活性和对映选择性，相应的炔丙基磺酰胺产物可取 得最高 $93 \%$ 的产率和 $87 \%$ 的 ee 值; 当使用直链烷基末 端炔底物时，反应的对映选择性有较为明显的下降，但 是支链末端炔底物依旧能以良好的的 $e e$ 值得到目标产 物. 

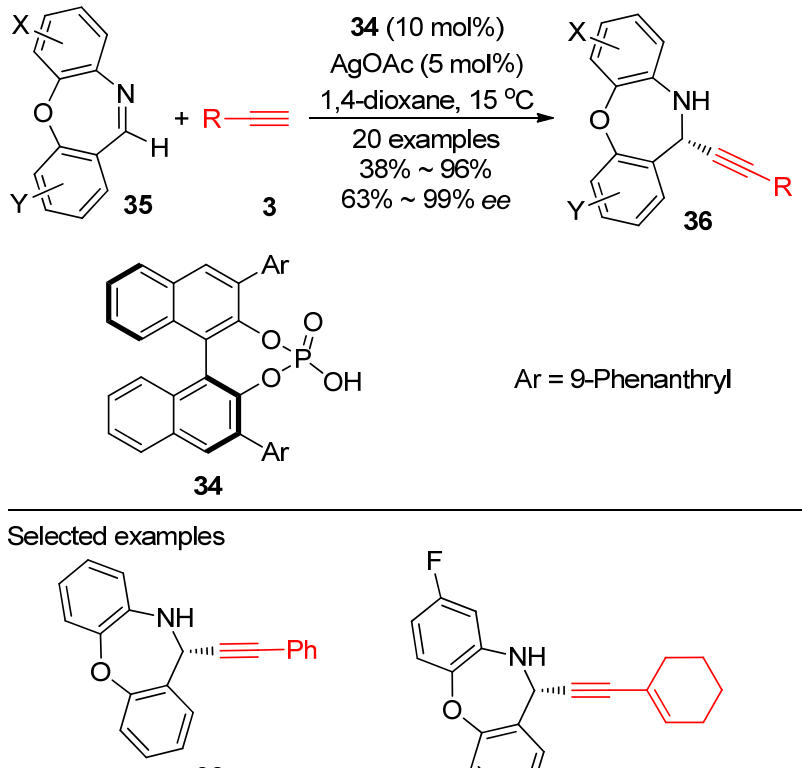

$36 \mathbf{a}$

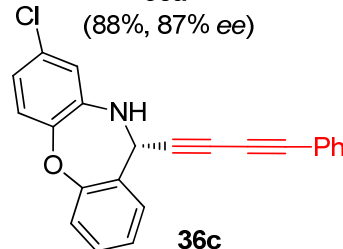

$(90 \%, 96 \%$ ee $)$

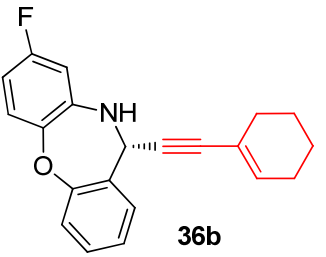

$(96 \%, 99 \%$ ee $)$

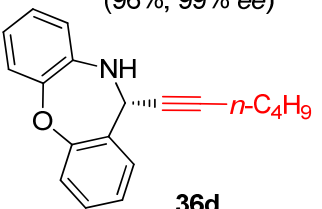

$(38 \%, 78 \%$ ee $)$

图式 11 七元环状亚胺的不对称炔基化反应

Scheme 11 Asymmetric alkynylation of 7-membered cyclic imine

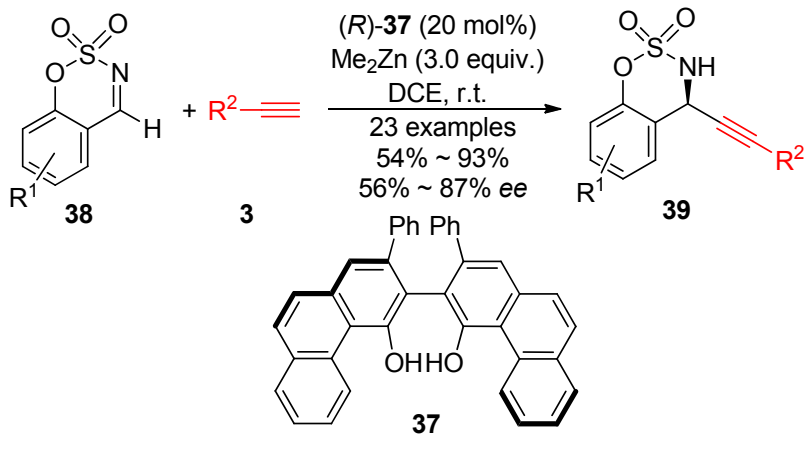

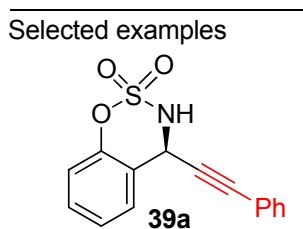

$(89 \%, 82 \%$ ee)

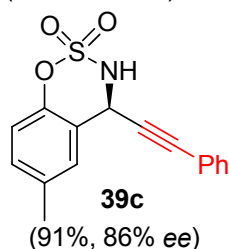

图式 12 苯并六元环状磺酰亚胺的不对称炔基化反应 Scheme 12 Asymmetric alkynylation of benzo[e][1,2,3]-oxathiazine 2,2-dioxides
此后，该课题组 ${ }^{[15]}$ 进一步研究发现使用廉价易得 的手性二芳基脯氨醇 40 作为配体也能实现上述反应 (Scheme 13). 相对之前的条件, 本反应有以下两个明显 的优势：使用更为廉价易得的配体和目标产物可取得普 遍更高的对映选择性. 尤其是对于烷基末端炔类底物参 与的反应，在之前的条件下仅能取得最高 $79 \%$ 的 $e e$ 值, 而在当前的条件下能取得高达 $91 \%$ 的对映选择性.

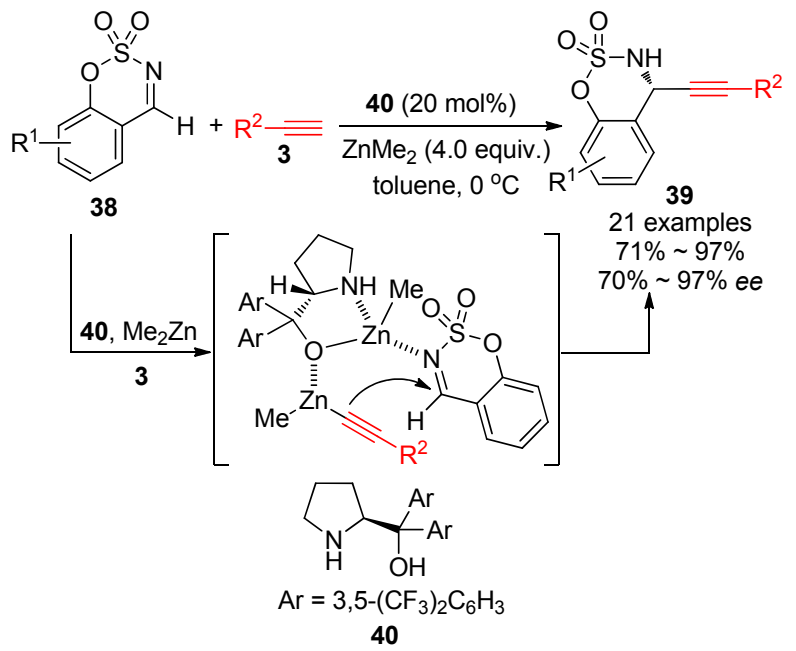

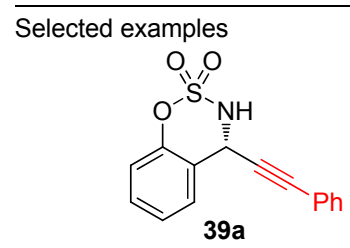

$(96 \%, 97 \%$ ee $)$

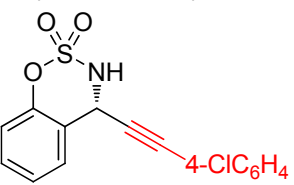

$39 \mathrm{c}$

$(97 \%, 90 \%$ ee $)$<smiles>Cc1cccc2c1OS(=O)(=O)N[C@H]2C#Cc1ccccc1</smiles>

$(85 \%, 94 \%$ ee)

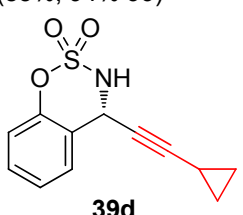

$4 \%, 91 \%$ ee
图式 13 脯氨醇作为配体催化的不对称炔基化反应

Scheme 13 Diarylprolinol as a ligand for enantioselective alkynylation

与非环状亚胺类似，环状亚胺也能通过现场制备的 方式来参与不对称炔基化反应。苏为科等 ${ }^{[16]}$ 报道了使 用 2,3-二氯-5,6-二氰基对苯醌(DDQ)作为氧化剂将 $N$-芳 基四氢异喹啉 41 氧化成相应的环状亚胺正离子 $\mathbf{A}$, 接 着与苯基 $\mathrm{PyBOX}$ 衍生的炔基铜发生不对称加成反应来 制备光学活性的 1-炔基四氢异喹啉衍生物 42 (Scheme 14). 有意思的是, 该反应不需要添加额外的铜盐作为 金属催化剂，也无需使用溶剂，仅需要在铜珠高速球磨 条件下就能顺利进行. 但是，目标产物的产率和对映选 择性还有待进一步提高.

刘否等 ${ }^{[17]}$ 使用 $2,2,6,6$-四甲基哌啶氮氧化物 $\left(\mathrm{T}^{+} \mathrm{BF}_{4}^{-}\right)$作为氧化剂实现了 $N$-酰基四氢异喹啉衍生物 


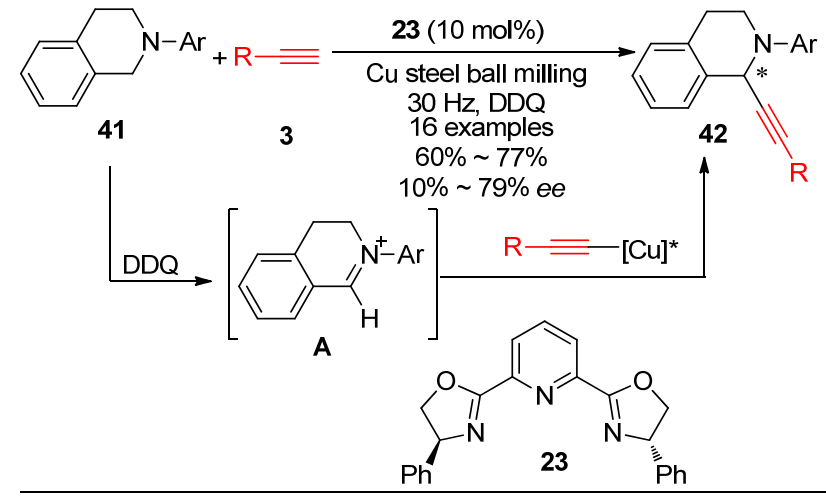

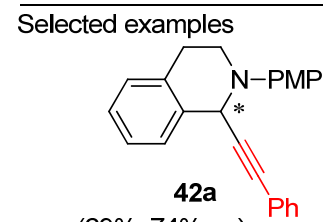

(69\%, 74\% ee)

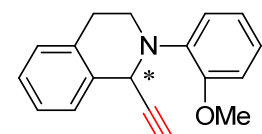

42c
(65\%, 34\% ee $)^{4-\mathrm{FC}_{6} \mathrm{H}_{4}}$
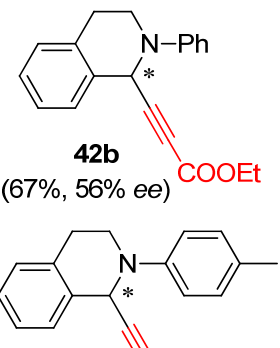

42d

$(72 \%, 62 \%$ ee) $\mathrm{COOMe}$
图式 14 高速球磨条件下的不对称炔基化反应

Scheme 14 Asymmetric alkynylation in a ball mill

与末端炔的交叉脱氢偶联反应(Scheme 15). 该文作者
认为, 在氧化剂的作用下, 43 首先被转化成亚胺中间体 A, 后者在 $\mathrm{Yb}(\mathrm{OTf})_{3}$ 的作用下与外加的 $\mathrm{EtOH}$ 发生加成 反应得到缩醛胺中间体 $\mathbf{B}$, 该中间体是另外一个相对稳 定亚胺 $\mathbf{C}$ 的前体, 它在体系中的浓度较高. 使用异丙基 取代的 $\mathrm{PyBOX}$ 与 $\mathrm{CuBr}$ 的络合物作为手性催化剂, 一系 列末端炔对亚胺 $\mathbf{C}$ 的加成反应可取得最高 $70 \%$ 的产率 和高达 $95 \%$ 的 $e e$ 值. 以上述不对称脱氢偶联反应作为 关键步骤, 他们还进一步实现了具有生物活性天然产物 Emetine 的全合成.

基于对上述反应的机理分析, 刘磊课题组 ${ }^{[18]}$ 进一 步使用基于四氢异喹啉的 $N$-酰基半缩醛胺 $\mathbf{4 8}$ 作为环状 亚胺正离子的前体化合物, 实现了 1-炔基四氢异喹啉衍 生物 49 的制备(Scheme 16). 在最佳条件下，该反应可 取得最高 76\% 的产率和高达 $99 \%$ 的对映选择性. 相对 上述方法而言, 本方法无需使用氧化剂和强碱，且操作 更为简便.

2015 年, 李朝军等 ${ }^{[19]}$ 利用光和铜协同催化实现了 $N$-芳基四氢异喹啉衍生物与末端炔的交叉脱氢偶联反 应(Scheme 17). 该文作者认为, $N$-芳基四氢异喹啉 41 在 光催化作用下, 经过单电子氧化得到高活性的亚胺正离 子中间体; 接着, 在手性 N,P-配体 $\mathbf{5 0}$ 与铜络合物催化 下，与末端炔发生不对称加成反应. 该反应具有较好的

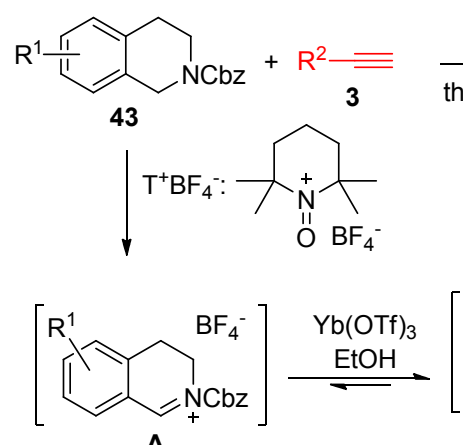

A

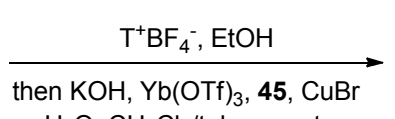

$\mathrm{H}_{2} \mathrm{O}, \mathrm{CH}_{2} \mathrm{Cl}_{2}$ /toluene, r.t.

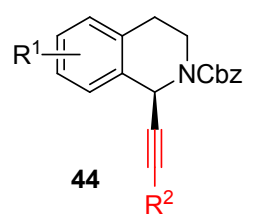

24 examples

$15 \% \sim 70 \%, 39 \% \sim 95 \%$ ee

$\mathrm{R}^{2}=\left[\mathrm{Cu}^{*}\right] \uparrow$<smiles>CCCC1COC(c2cccc(C3=NC(C(C)C)CO3)n2)C1</smiles>

Synthetic application<smiles>COc1cc2c(cc1OC)CN(C(=O)OCc1ccccc1)CC2</smiles>

$43 a$

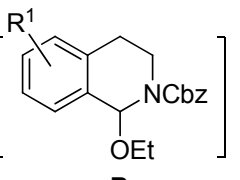

B

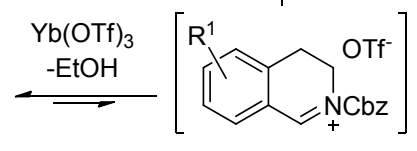

C
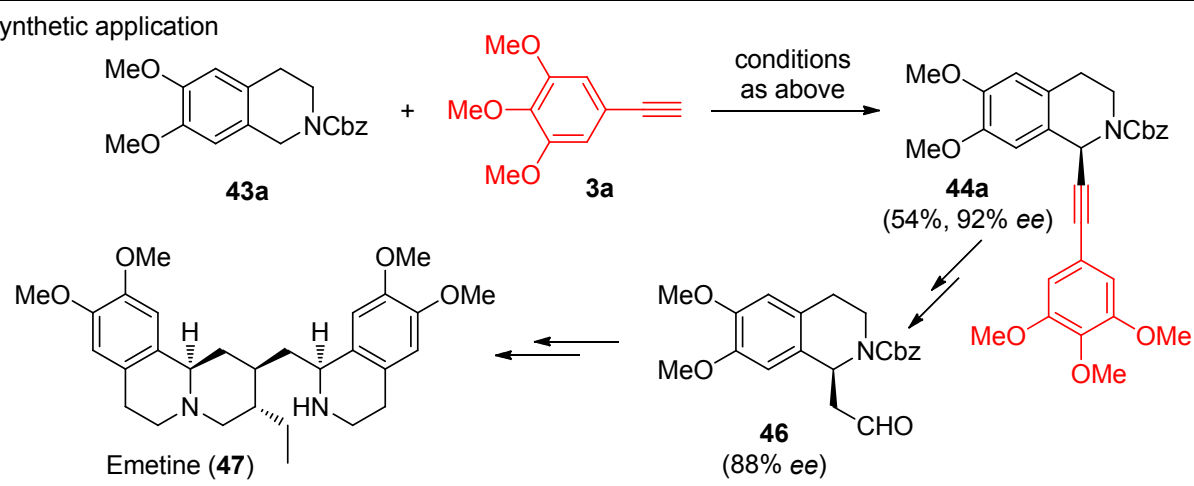

图式 $15 N$-酰基四氢异喹啉衍生物与末端炔的交叉脱氢偶联反应

Scheme 15 Enantioselective catalytic cross-dehydrogenative coupling (CDC) of $N$-carbamoyl tetrahydroisoquinolines and terminal alkynes 

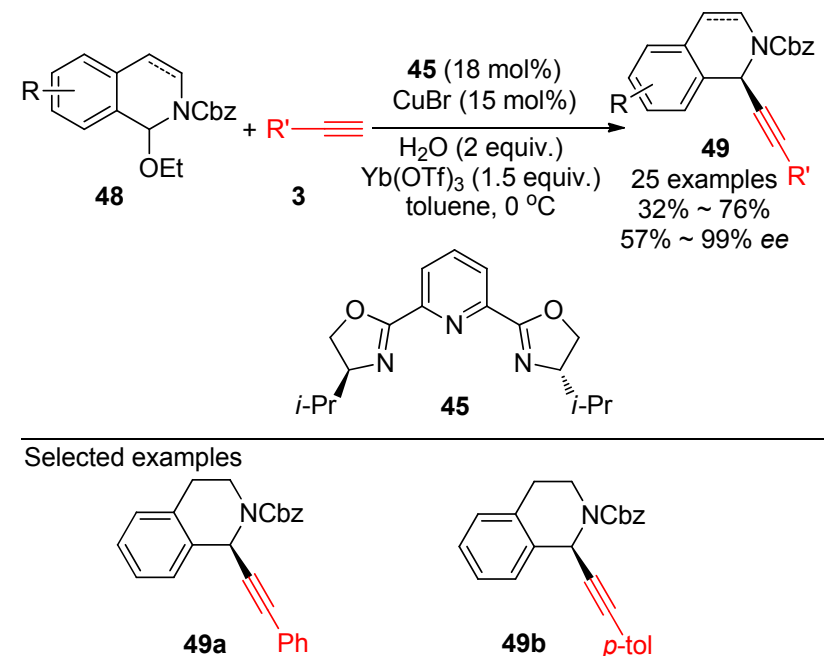

$(67 \%, 97 \%$ ee)

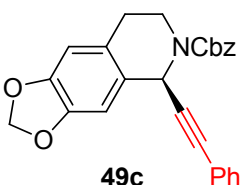

$(62 \%, 97 \%$ ee $)$

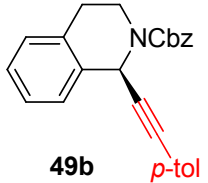

$(68 \%, 96 \%$ ee $)$

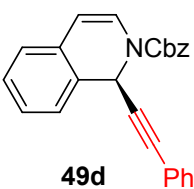

$(56 \%, 90 \%$ ee $)$

图式 16 基于四氢异喹啉的 $N$-酰基半缩酫胺的不对称炔基化

反应

Scheme 16 Enantioselective alkynylation of tetrahydroisoquinoline based $N$-acyl hemiaminals

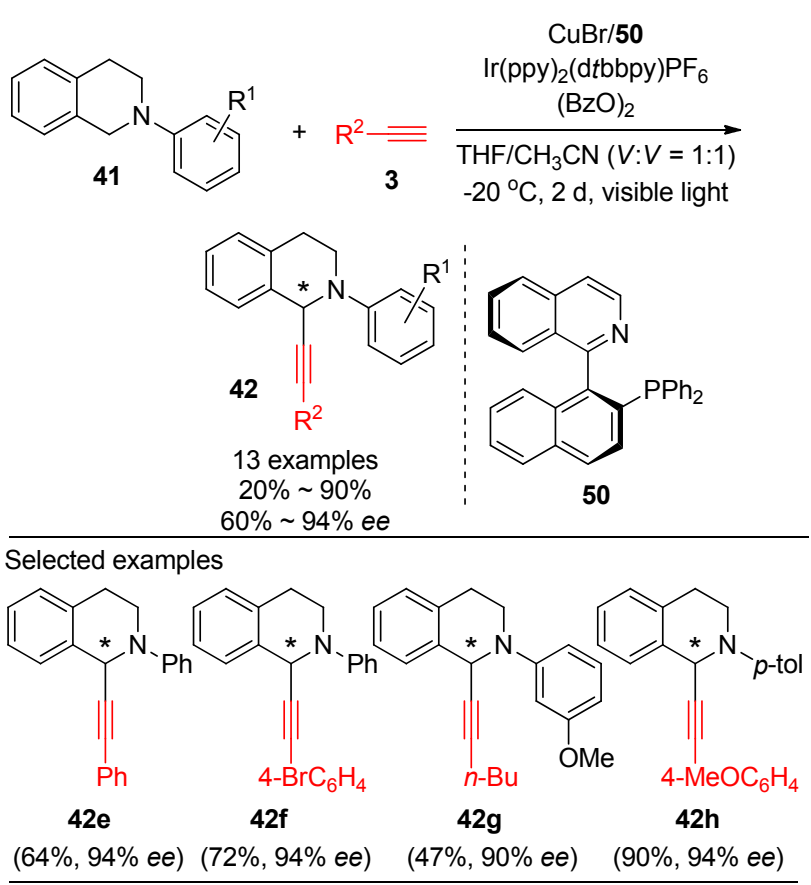

图式 17 协同催化的四氢异喹啉与末端炔的交叉脱氢偶联反 应

Scheme 17 Synergistic photocatalytic and copper-catalyzed CDC reaction between tertiary amines and terminal alkynes

底物兼容性, 即使是直链末端炔的反应也能取得高达

90\%的对映选择性.

稍后，冯小明和刘小华等 ${ }^{[20]}$ 研究发现，使用氧气作 为氧化剂也能实现上述交叉脱氢偶联反应(Scheme 18). 利用他们发展的冯氏氮氧配体 51 与 $\mathrm{Zn}(\mathrm{NTf})_{2}$ 和 $\mathrm{Fe}(\mathrm{OTf})_{2}$ 形成的双金属协同催化体系, 在 $101 \mathrm{kPa}$ 的氧 气存在下，一系列芳环上带有不同电性和位阻的取代基 的 $N$-芳基四氢异喹啉和芳基末端炔的不对称脱氢偶联 都能顺利进行，并以最高 $82 \%$ 的产率和高达 $99 \%$ 的对映 选择性得到相应的目标产物. 虽然，该反应对烷基末端 炔的兼容性较差，产物的对映选择性普遍不理想，但使 用环境友好的氧气作为氧化剂，反应的原子经济性明显 更高，因而更具实用性.

\section{1}

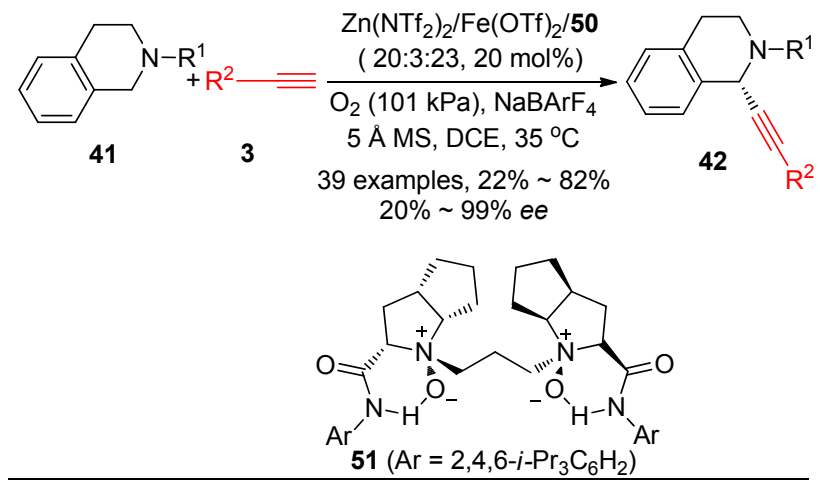

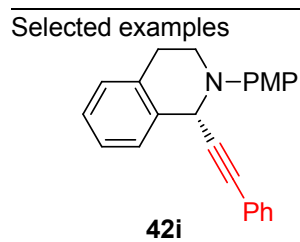

$(70 \%, 93 \%$ ee $)$

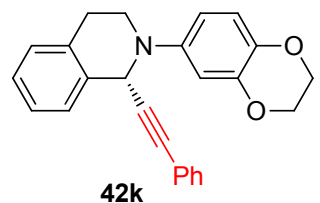

$(50 \%, 99 \%$ ee $)$

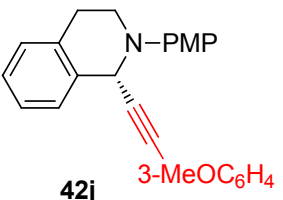

$(82 \%, 93 \%$ ee $)$

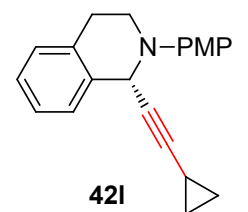

$(42 \%, 88 \%$ ee)
图式 18 双金属协同催化的交叉脱氢偶联反应

Scheme 18 Bimetallic cooperatively catalyzed cross-dehydrogenative coupling $(\mathrm{CDC})$ reaction

\section{3 不对称 $A^{3}$ 反应}

自从李朝军课题组 ${ }^{[21]}$ 于 2002 年报道了芳香醛 (Aldehyde)、伯胺(Amine)和末端炔(Alkyne)的三组分 $\left(\mathrm{A}^{3}\right)$ 不对称反应来制备手性炔丙胺化合物以来，由于该反应 的起始原料广泛易得、操作简便、反应条件温和、原子 经济性高等优势，得到了合成化学家们的广泛关注.

1.3.1 手性双噁唑啉和双味唑啉三齿配体铜络合物 催化

自从李朝军等在首例不对称 $\mathrm{A}^{3}$ 反应使用了手性双 
啞唑啉三齿配体 PyBOX 以来, 该类配体及其类似物在 开发新型对映选择性 $\mathrm{A}^{3}$ 反应中得到持续关注. 2014 年, Singh 等 ${ }^{[22]}$ 利用 PyBOX 配体衍生的 $\mathrm{Cu}(\mathrm{I})$ 络合物实现了 一例串联不对称炔基化/内酰胺化反应来合成光学活性 的异吲哚啉酮衍生物(Scheme 19). 经过一系列配体结 构考察, 作者最终发现使用大位阻的 PyBOX 配体 52 和 CuOTf 的络合物作为催化剂时, 2-甲酰基苯甲酸酯 $\mathbf{5 3}$ 与 芳香胺 54 以及末端炔 3 的三组分串联能以 $63 \% \sim 98 \%$ 的产率和最高 $99 \%$ 的对映选择性得到一系列手性异吲 哚啉酮衍生物 55. 反应大致经历如下历程: 2-甲酰基苯 甲酸酯和芳香胺现场发生分子间缩合反应得到亚胺，后 者接受炔基铜络合物的进攻产生的氮负离子顺势与分 子内的酯基发生亲核加成消除反应得到最终的异吲哚 啉酮衍生物.

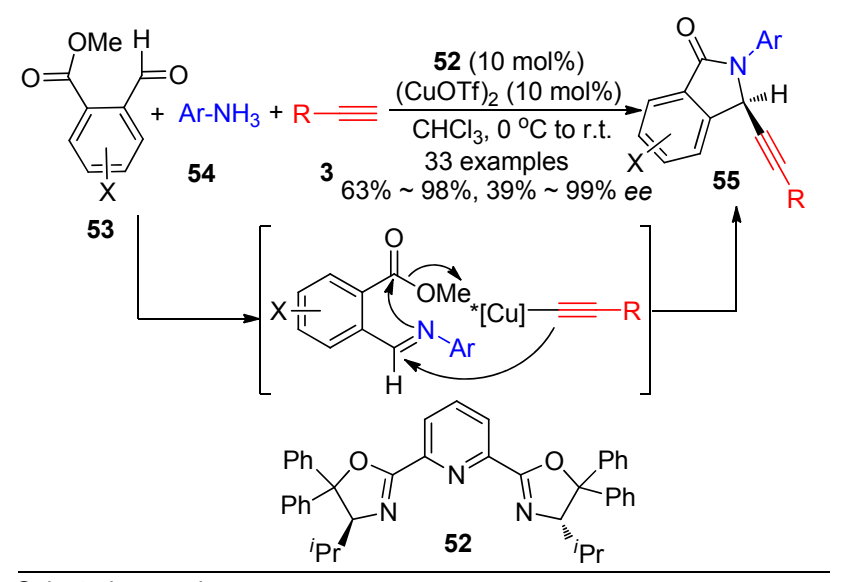

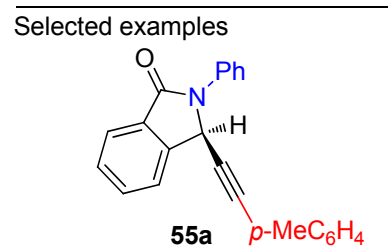

$(87 \%, 96 \%$ ee $)$

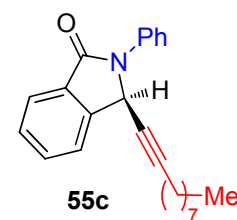

$(89 \%, 90 \%$ ee $)$

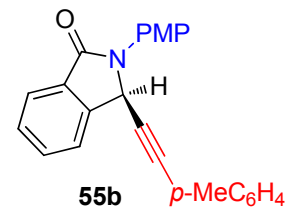

$(88 \%, 94 \%$ ee $)$

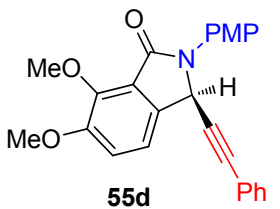

$(85 \%, 92 \%$ ee $)$
图式 19 串联不对称炔基化/内酰胺化合成异吲哚啉酮衍生物 Scheme 19 Cascade asymmetric alkynylation/lactamization to enantiomerically enriched isoindolinones

在上述工作的基础上, 他们 ${ }^{[23]}$ 进一步发展了一锅 法三组分串联亚胺形成/不对称炔基化/氮杂 Michael 反 应来对映选择性合成 1,3 二取代异吲哚啉和四氢异喹啉 衍生物 57, 反应可取得最高 $99 \%$ 的 ee 值(Scheme 20a); 从 2-乙炔基苯胺 58、芳香醛 59 和苯胺 54 出发, Singh 等 ${ }^{[24]}$ 使用 PyBOX-Cu(I) 和 $N-B o c$ 保护的脯氨酸协同催化
还实现了一系列 2-吲哚基手性二级胺衍生物 60 的合成 (Scheme 20b).

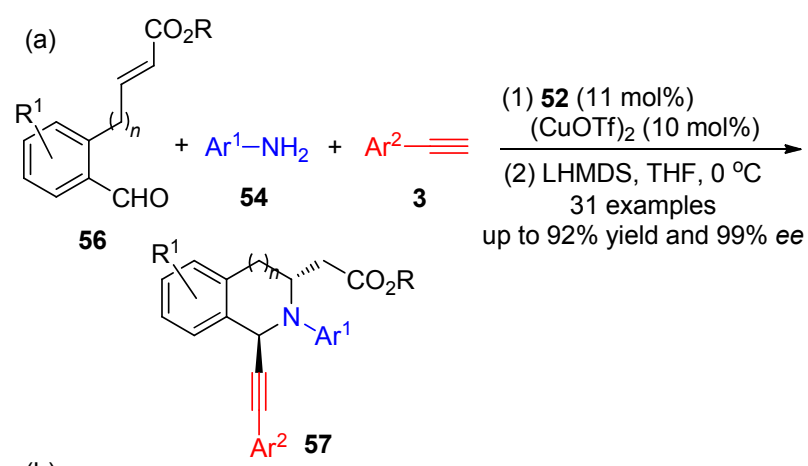

(b)

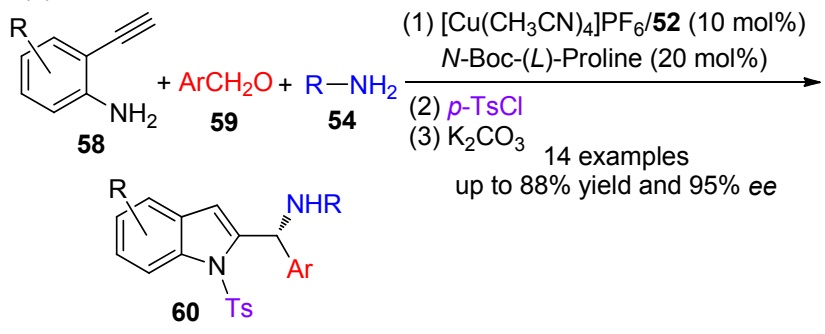

图式 20 基于不对称 $\mathrm{A}^{3}$ 反应的串联反应

Scheme 20 Cascade reactions based on asymmetric $A^{3}$ reaction

在前期发展了高振动球磨条件下亚胺的不对称炔 基化反应的基础上(Scheme 14), 苏为科课题组 ${ }^{[25]}$ 进一 步探究了该体系在不对称 $\mathrm{A}^{3}$ 反应中的应用(Scheme 21). 使用 $\mathrm{Ph}-\mathrm{PyBOX}$ 与 $\mathrm{Cu}(\mathrm{OTf})_{2}$ 的络合物作催化剂, 在硅胶 和不锈钢珠中进行研磨，一系列芳香醛、芳香胺与芳基 和烷基末端炔的不对称 $\mathrm{A}^{3}$ 反应可以 $90 \% \sim 99 \%$ 的产率 和最高 $99 \%$ 的 $e e$ 值得到目标炔丙胺产物 61. 与传统的 在溶液中进行的反应相较而言, 本反应无需使用有机溶 剂，反应时间短，催化剂可重复回收利用，因而是一种 更为绿色环保的合成方法.

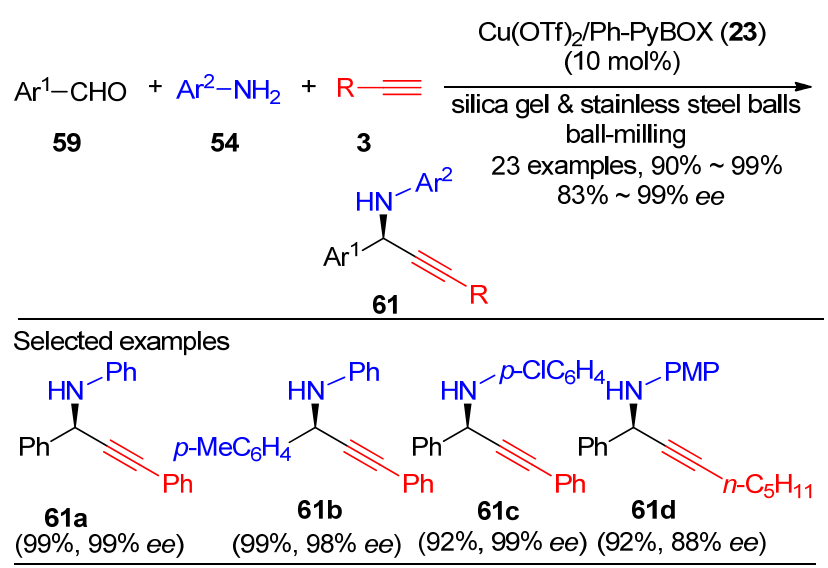

图式 21 高速球磨条件下的不对称 $\mathrm{A}^{3}$ 反应

Scheme 21 Asymmetric $A^{3}$ reaction under ball-milling conditions

基于他们在发展 $\mathrm{CO}_{2}$ 作为 $\mathrm{C} 1$ 合成子的不对称催化 
新反应的研究兴趣, 周剑和周锋等 ${ }^{[26] 于 ~} 2017$ 年报道了 一例手性 $\mathrm{Cu}(\mathrm{II})$ 络合物和 $\mathrm{Ag}(\mathrm{I})$ 串联催化的不对称 $\mathrm{A}^{3}$ 环 羧基化反应来合成一系列光学活性 $N$-芳基噁唑烷酮衍 生物(Scheme 22). 反应历程大致如下: 在该课题新发展 的 PyBOX 配体 63 和 $\mathrm{Cu}(\mathrm{OTf})_{2}$ 络合物的催化下, 芳香 醛、芳基伯胺和芳基末端炔首先发生不对称 $\mathrm{A}^{3}$ 反应得 到手性炔丙胺中间体 $\mathbf{A} ; \mathbf{A}$ 在 $\operatorname{Ag}(\mathrm{I})$ 、二苯基胍(DPG)以 及手性铜络合物的共同作用下与 $\mathrm{CO}_{2}$ 发生环羧基化反 应即可以 44\% 99\%的产率和 90\% 96\%的对映选择性 的达到目标 $N$-芳基啞唑烷酮 62. 值得注意的是, 作者通 过对照实验发现, 第一步反应的手性铜络合物催化剂对 后续的环羧基化反应有明显的加速作用.
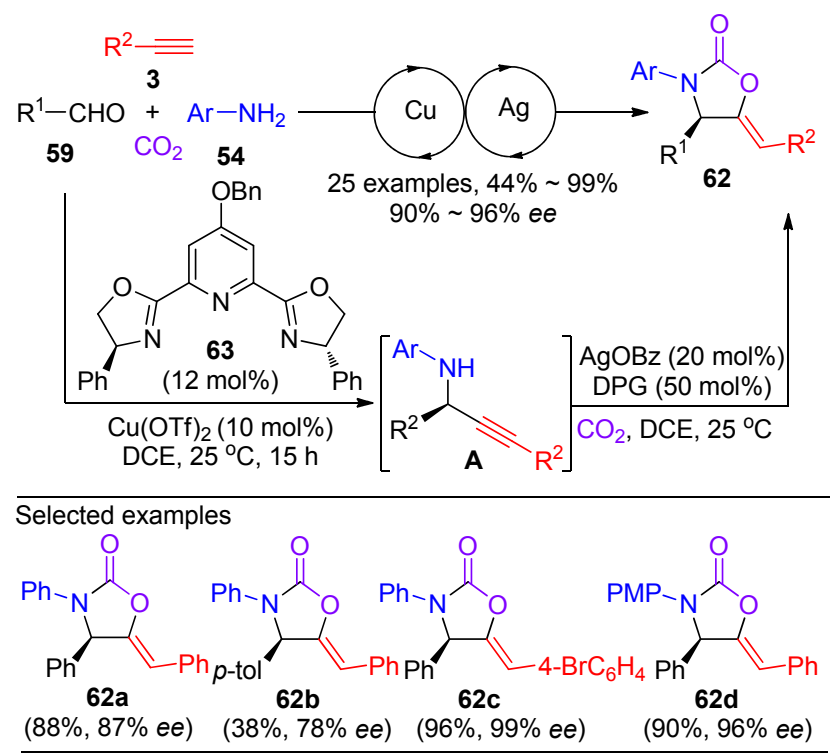

图式 22 串联不对称 $\mathrm{A}^{3} /$ 环羧基化合成啞唑烷酮衍生物

Scheme 22 Tandem asymmetric $\mathrm{A}^{3}$ coupling-carboxylative cyclization sequence to 2-oxazolidinones

虽然手性 PyBOX 类配体在不对称 $\mathrm{A}^{3}$ 反应中有着不 俗的表现, 但是从上述的介绍中不难看出, 高对映选择 性的反应大多局限在芳基末端炔底物, 脂肪族直链末端 炔的反应结果大多不理想. Nakamura 课题组 ${ }^{[27]}$ 设想能 否利用他们课题组发展的手性双咪唑啉三齿配体来实 现脂肪族直链末端炔参与的高对映选择性 $\mathrm{A}^{3}$ 反应. 经 过一系列尝试, 他们 ${ }^{[28]}$ 最终发现, 手性双咪唑啉 64 衍 生的 $\mathrm{Cu}(\mathrm{I})$ 络合物可以高效高对映选择性地催化芳香醛、 芳香胺和脂肪族直链末端炔 $\mathrm{A}^{3}$ 反应，相应的炔丙胺产 物可取得高达 $98 \%$ 的对映选择性(Scheme 23), 苯乙炔和 乙炔基三甲基硅烷的反应也能分别取得 $95 \%$ 和 $92 \%$ 的 $e e$ 值.

此后, Nakamura 等 ${ }^{[29]}$ 进一步发展了一例水相中的 不对称 $\mathrm{A}^{3}$ 反应(Scheme 24). 使用他们自己所发展的手 性双咪唑啉三齿配体 66 和 CuOTf 所形成的络合物作为 催化剂, 十二烷基硫酸钠(SDS)作为表面活性剂, 一系
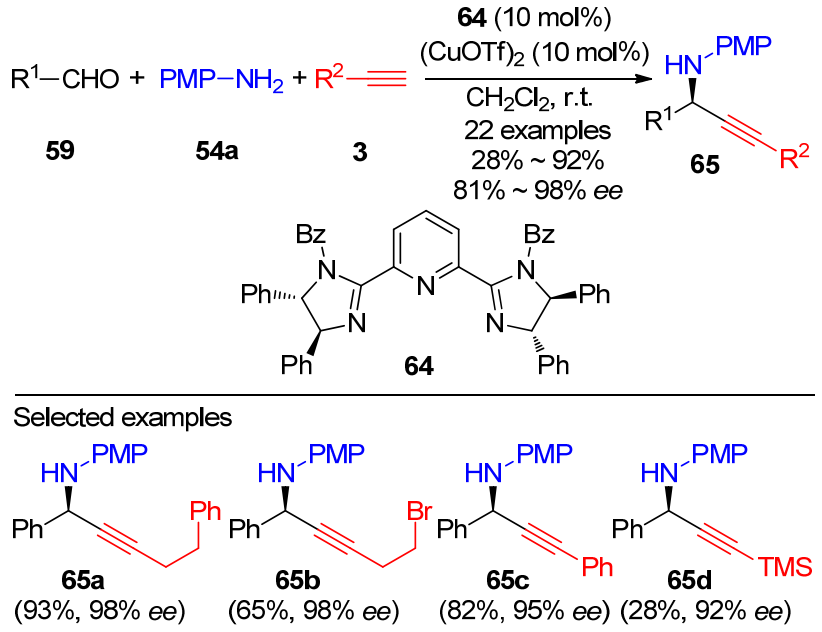

图式 23 手性双咪唑啉三齿配体参与催化的 $\mathrm{A}^{3}$ 反应 Scheme 23 Chiral bis(imidazoline)-Cu(I) catalyzed $\mathrm{A}^{3}$ reaction

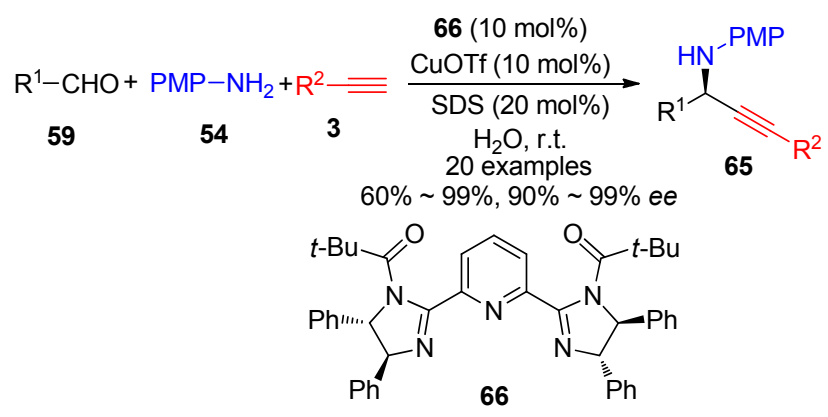

Selected examples

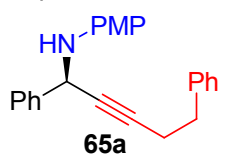

$(99 \%, 98 \%$ ee $)$

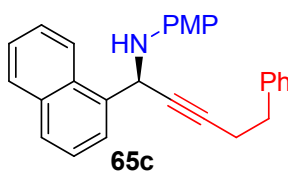

$(91 \%, 92 \%$ ee $)$

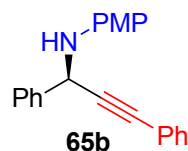

$(99 \%, 98 \%$ ee)

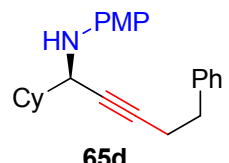

$(66 \%, 98 \%$ ee)
图式 24 手性双咪唑啉- $\mathrm{Cu}(\mathrm{I})$ 络合物催化的在水相中的 $\mathrm{A}^{3}$ 反 应

Scheme 24 Chiral bis(imidazoline)-Cu(I) complex catalyzed $\mathrm{A}^{3}$ reaction in water

列芳香醛、芳香胺与烷基取代末端炔的反应均能在水相 中顺利进行，并以 $60 \%$ 99\%的产率和优秀的对映选择 性生成目标炔丙胺产物. 此外, 脂肪醛、芳香末端炔在 上述条件下也能取得高达 $98 \%$ 的 ee 值.

\subsection{2 手性 N-PINAP 配体一铜络合物催化}

手性 $N$-PINAP 配体最早由 Carreira 等 ${ }^{[30]}$ 于 2004 年 设计合成，并初步尝试了它的 $\mathrm{Cu}(\mathrm{I})$ 络合物在不对称 $\mathrm{A}^{3}$ 反应中催化效果. 此后, 麻生明课题组 ${ }^{[31]}$ 对该类配体在 不对称 $\mathrm{A}^{3}$ 反应中的应用进行了系统的研究，并将相关 
反应广泛应用到天然产物和药物活性分子的全合成中.

在 2012 年, 麻生明等 ${ }^{[32]}$ 以 $(R, R)-N-\mathrm{PINAP}-\mathrm{Cu}(\mathrm{I})$ 络 合物催化的不对称 $\mathrm{A}^{3}$ 作为关键步骤实现了手性联烯化 合物的不对称合成(Scheme 25). 首先, 炔丙醇 67、脂肪 醛 59 和四氢吡咯 68 发生不对称 $\mathrm{A}^{3}$ 反应得到手性炔丙 胺中间体 $\mathbf{A}$; 接着, $\mathrm{A}$ 在碘化锌的作用下发生分子内氢 转移反应得到烯基锌中间体 $\mathbf{C}$, 后者经 1,2-消除反应即 能以中等到良好的产率和优秀的对映选择性得到最终 的手性联烯产物 69. 除了脂肪醛底物, 芳香醛也能适用 于该反应并取得优秀的 $e e$ 值. 最近, 他们研究发现用氮 杂环辛烷替代四氢吡咯时, 仅使用 $N-\mathrm{PINAP}-\mathrm{Cu}(\mathrm{I})$ 就能 实现上述转化, 且催化剂的用量可以降低至 $2.5 \mathrm{~mol} \%$.
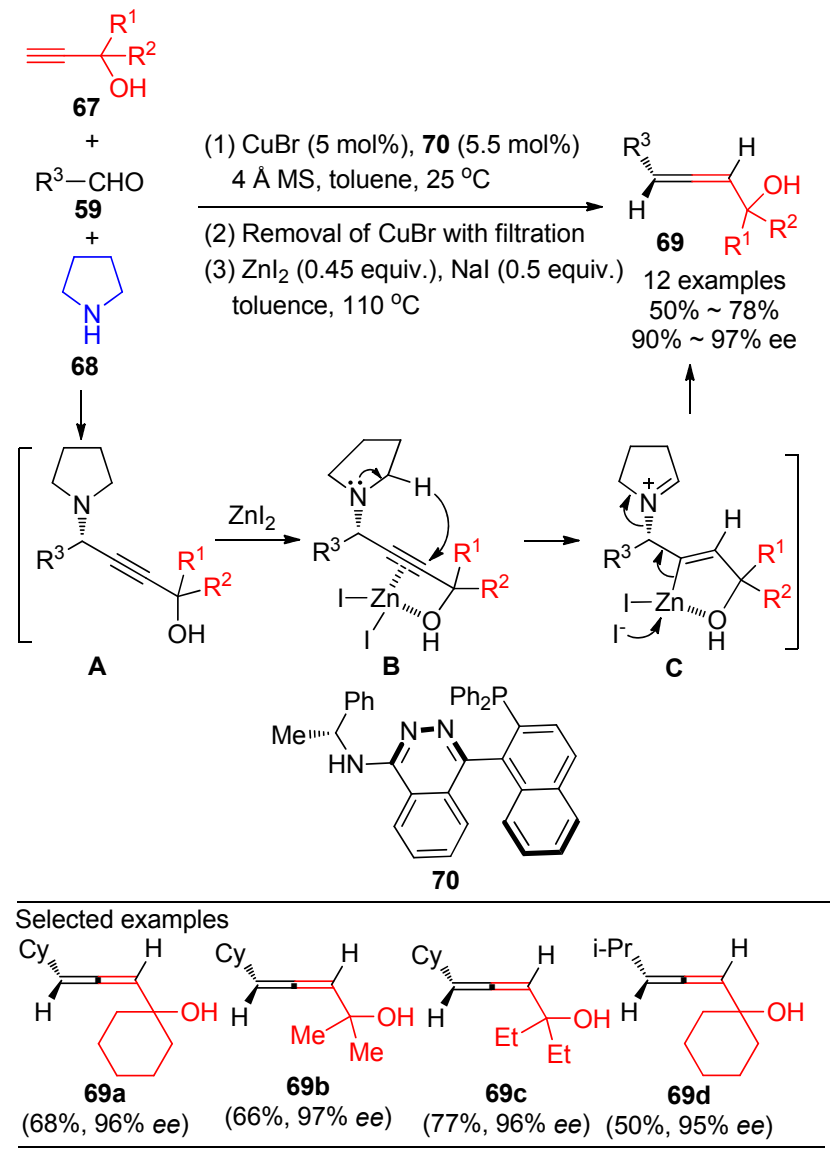

图式 25 从末端炔出发制备手性联烯

Scheme 25 Synthesis of chiral allenes from terminal alkynes

2013 年, 他们 ${ }^{[33]}$ 进一步对 $(R, R)-N-\mathrm{PINAP}-\mathrm{Cu}(\mathrm{I})$ 络 合物催化的不对称 $\mathrm{A}^{3}$ 反应的底物普适性进行了考察 (Scheme 26). 结果表明, 该反应对一系列芳香醛和脂肪 醛均展示了很好的兼容性, 相应的炔丙胺产物都能取得 优秀的对映选择性. 值得注意的, 2-甲基-3-丁炔-2-醇 67 的使用对反应取得优秀的对映选择性至关重要, 当使用 炔丙醇和三甲基乙炔基硅烷时, 反应的对映选择性出现 了明显的下降. 此外, 产物中的 2-着基-丙基可以在强
碱作用下高效脱除得到末端炔丙胺产物 72, 并且反应 可以扩大到克级规模进行.

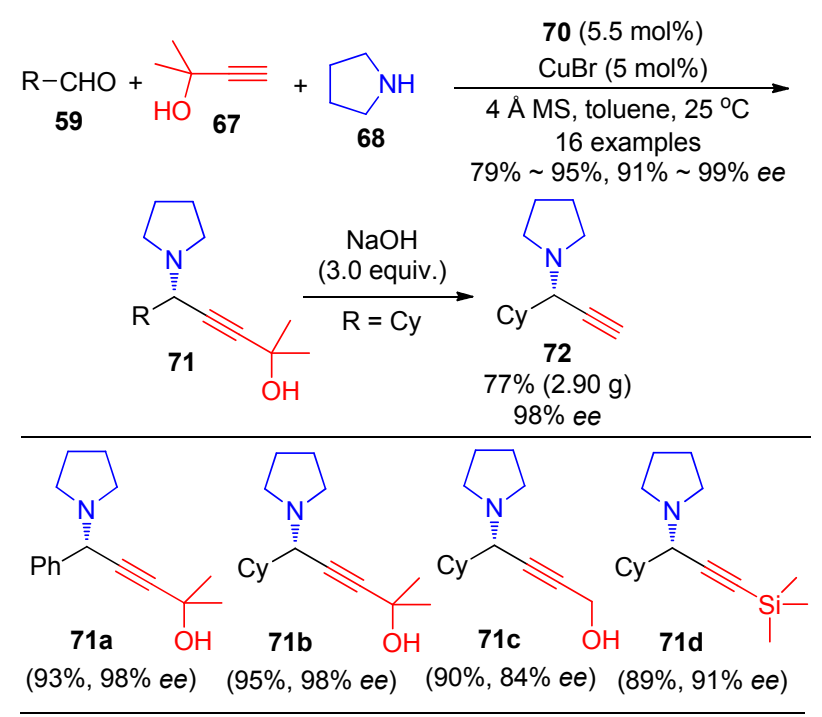

图式 $26(R, R)-N-\mathrm{PINAP}-\mathrm{Cu}(\mathrm{I})$ 络合物催化的不对称 $\mathrm{A}^{3}$ 反应 Scheme $26(R, R)-N$-PINAP-Cu(I) complex catalyzed $\mathrm{A}^{3}$ reaction

此后，他们 ${ }^{[34]}$ 利用 2-甲基-3-丁炔-2-醇、脂肪醛和 1,4-二氢吡咯不对称 $\mathrm{A}^{3}$ 反应所得的手性炔丙胺作为关 键中间体实现了手性 $N$-烯丙基吡咯衍生物 73 的合成 (Scheme 27). 经过细致的机理研究, 该文作者认为手性 炔丙胺产物在铜催化下, 经历了两次氢转移得到最终的 $N$-烯丙基吡咯衍生物.

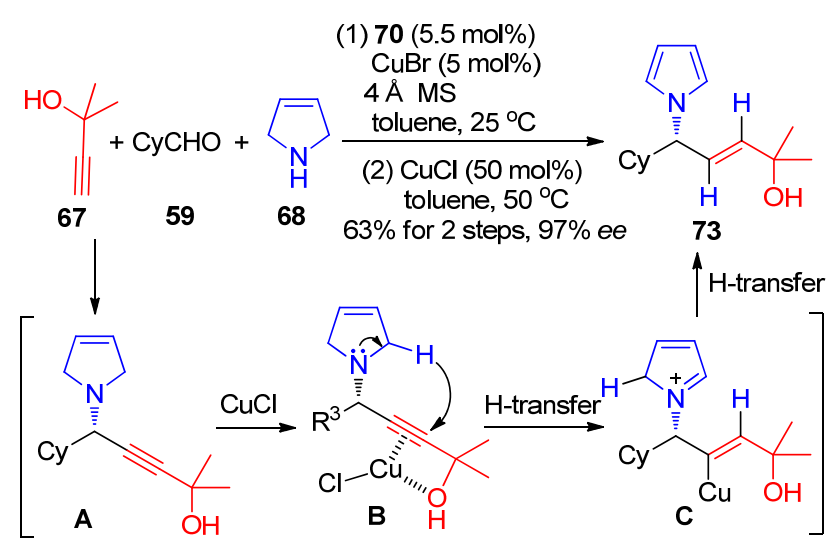

图式 27 从末端炔出发制备 $N$-烯丙基吡咯衍生物 Scheme 27 Synthesis of chiral $N$-allyl pyrrole from alkynes

同年，该课题组 ${ }^{[35]}$ 还从简单易得的取代四氢异喹 啉、芳香醛和末端炔出发, 利用手性 $N$-PINAP 配体一铜 络合物催化, 实现了一系列 C(1)含有手性中心的四氢异 喹啉的不对称合成. 通过该反应可以在四氢异喹啉的 $\mathrm{C}(1)$ 位高效高对映选择性地引入一系列的简单的直链 烷基、官能团化的烷基以及芳基. 在体系中，苯甲酸的 加入可以使反应在相对较低的温度下进行, 从而保证了 
反应在取得高对映选择性的同时获得优秀的产率 (Scheme 28). 利用上述四氢异喹啉参与的不对称 $\mathrm{A}^{3}$ 反 应作为关键步骤, 他们还分别于 2014 年和 2017 年实现 了异喹啉类生物碱 $(+)$-dysoxyline、 $(+)$-crispine A、 $(-)$-trolline 和 $(+)$-oleracein $\mathrm{E}$ 等的不对称全合成.
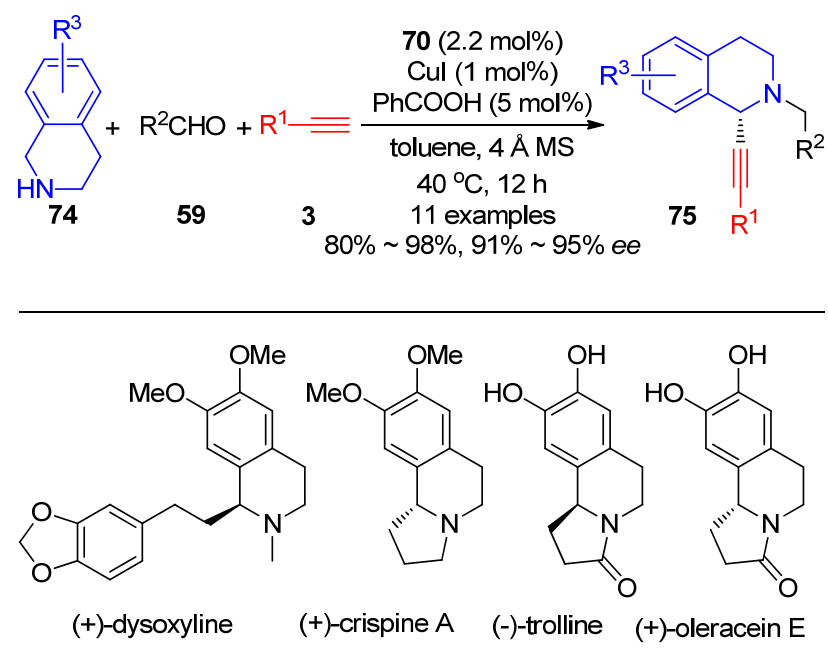

图式 28 四氢异喹啉参与的不对称 A3 反应及其应用 Scheme 28 Tetrahydroisoquinoline based asymmetric A3 reaction and its application

受上述麻生明课题组的研究工作启发, 童荣标 等 ${ }^{[36]}$ 从 $N$-PINAP 配体-铜催化的四氢异喹啉 74、邻溴苯 甲醛 59 和乙炔基三甲基硅烷 3 之间的不对称 $\mathrm{A}^{3}$ 反应出 发, 通过后续 Pd 催化的分子内还原 Heck 环化反应以及 $\mathrm{PtO}_{2}$ 催化的氢化, 完成了多达 12 个 13-甲基四氢原小檗 碱类生物碱的对映选择性全合成(Scheme 29).
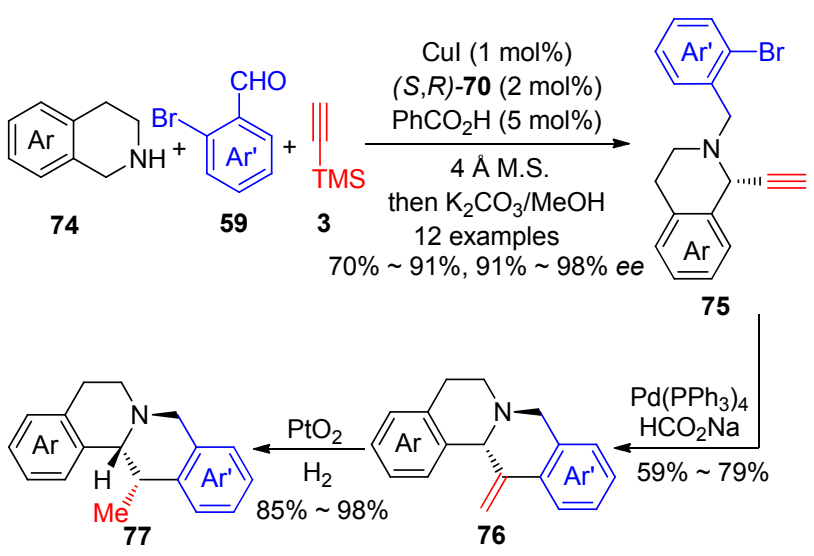

图式 29 13-甲基四氢原小檗碱类生物碱的对映选择性全合 成

Scheme 29 Asymmetric total syntheses of 13-methyltetrahydroprotoberberine alkaloids

\subsection{3 手性 StackPhos 类配体一铜络合物催化}

2013 年, Aponick 等 ${ }^{[37]}$ 从 2-羟基-1-菜甲醛出发, 经
过 6 步反应，首次完成了基于咪唑骨架的联芳基 N,P-配 体 80 的外消旋合成. 接着, 他们以 $\mathrm{CuBr}$ 催化的正丁醛、 乙炔基三甲基硅烷和二苠胺之间的 $\mathrm{A}^{3}$ 反应作为模板反 应, 并对照了 80 和传统的 N,P-配体, 发现使用 80 作为 配体可大大缩短反应时间，即使在 $0{ }^{\circ} \mathrm{C}$ 下，使用 80 的 反应依旧能在 $24 \mathrm{~h}$ 内完成并取得优秀的产率. 基于上述 结果，他们通过手性拆分以 $98 \%$ 的 $e e$ 值得到了手性的 (S)-80 并尝试了其在催化乙炔基醛、三甲基硅烷和二芐 胺之间的不对称 $\mathrm{A}^{3}$ 反应(Scheme $\left.30, \mathrm{a}\right)^{[37 \mathrm{a}]}$, 结果表明, 不管是脂肪醛还是芳香醛类底物, 反应都能顺利进行并 取得高达 $97 \%$ 的 $e e$ 值.
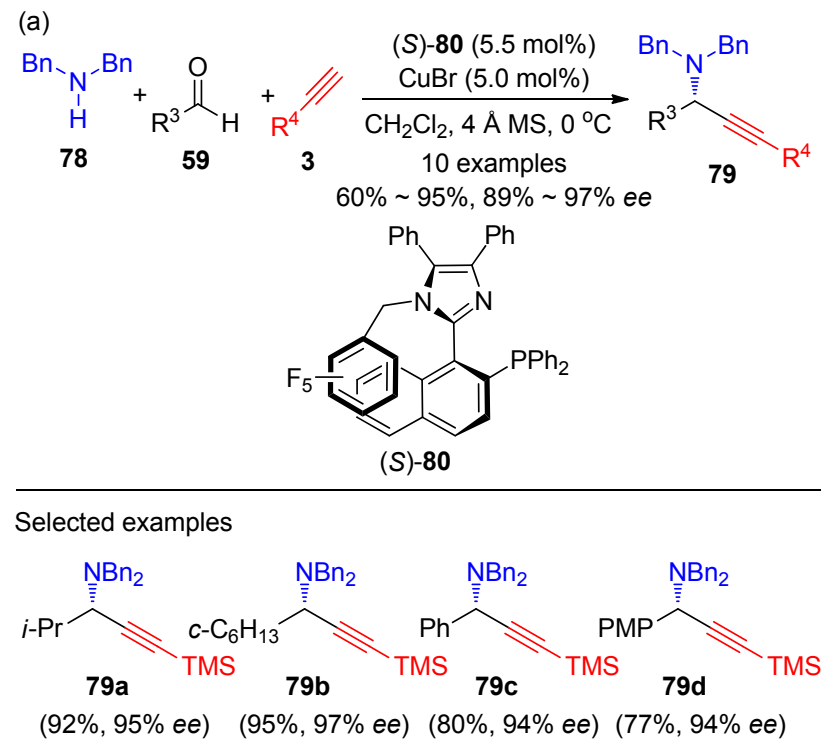

(b)

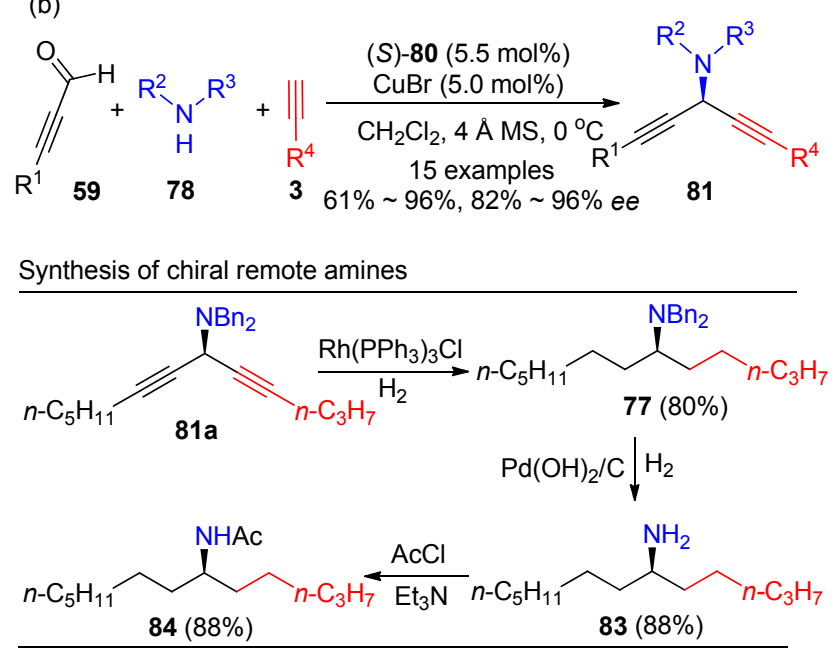

图式 30 手性 StackPhos 配体-铜络合物催化的不对称 $\mathrm{A}^{3}$ 反应 Scheme 30 Chiral stackPhos-Cu(I) complex catalyzed enantioselective $\mathrm{A}^{3}$ reaction and its application

此后，该课题组 ${ }^{[37 b]}$ 利用 StackPhos 配体一铜络合物 作催化剂，以炔基醛、二烷基胺和末端炔为原料，首次 
实现了手性 3-氨基隔离二炔(skipped diynes)81 的不对称 合成(Scheme 30, b). 由于产物中带有两个可以进行多 样性转化的炔键, 因此光学活性的 81 可以发生氢胺化、 Pauson-Khand 和二炔的双官能团化等反应来合成系列 新颖的手性分子. 此外, 从炔丙胺产物 $81 \mathrm{a}$ 出发, 经过 3 步简单转化, 即可实现天然产物 84 的手性全合成.

基于 StackPhos 在不对称 $\mathrm{A}^{3}$ 反应中的优异表现， Aponick 和 Guiry 课题组 ${ }^{[38]}$ 于 2017 年同时报道了一类 StackPhos 类似物(StackPhim)的合成和应用(Scheme 31). 由于在配体中进一步引入了两个手性中心, StackPhim
相比 StackPhos 具有更多的可修饰位点和更好的可调控 性. Aponick 等 ${ }^{[38 \mathrm{a}]}$ 首先利用 $(R, R, R)$-StackPhim 85 与 $\mathrm{CuBr}$ 的配合物作为催化剂, 实现了外消旋炔丙醇 86、醛和二 级胺的不对称 $\mathrm{A}^{3}$ 反应来合成一系列光学活性氨基二醇 87, 后者在阳离子 $\mathrm{Au}(\mathrm{I})$ 络合物的催化下, 可以发生分 子内环化反应得到一系列在天然产物中广泛存在的手 性 2-氨烷基呋喃衍生物(Scheme 31, a).

Guiry 等则探究了他们合成的 $(S, S, R)$-StackPhim 85 在醛、末端炔以及二茮胺之间的 $\mathrm{A}^{3}$ 反应中的催化效果 (Scheme 31, b $)^{[38 b]}$. 该文作者发现，该反应对脂肪醛类

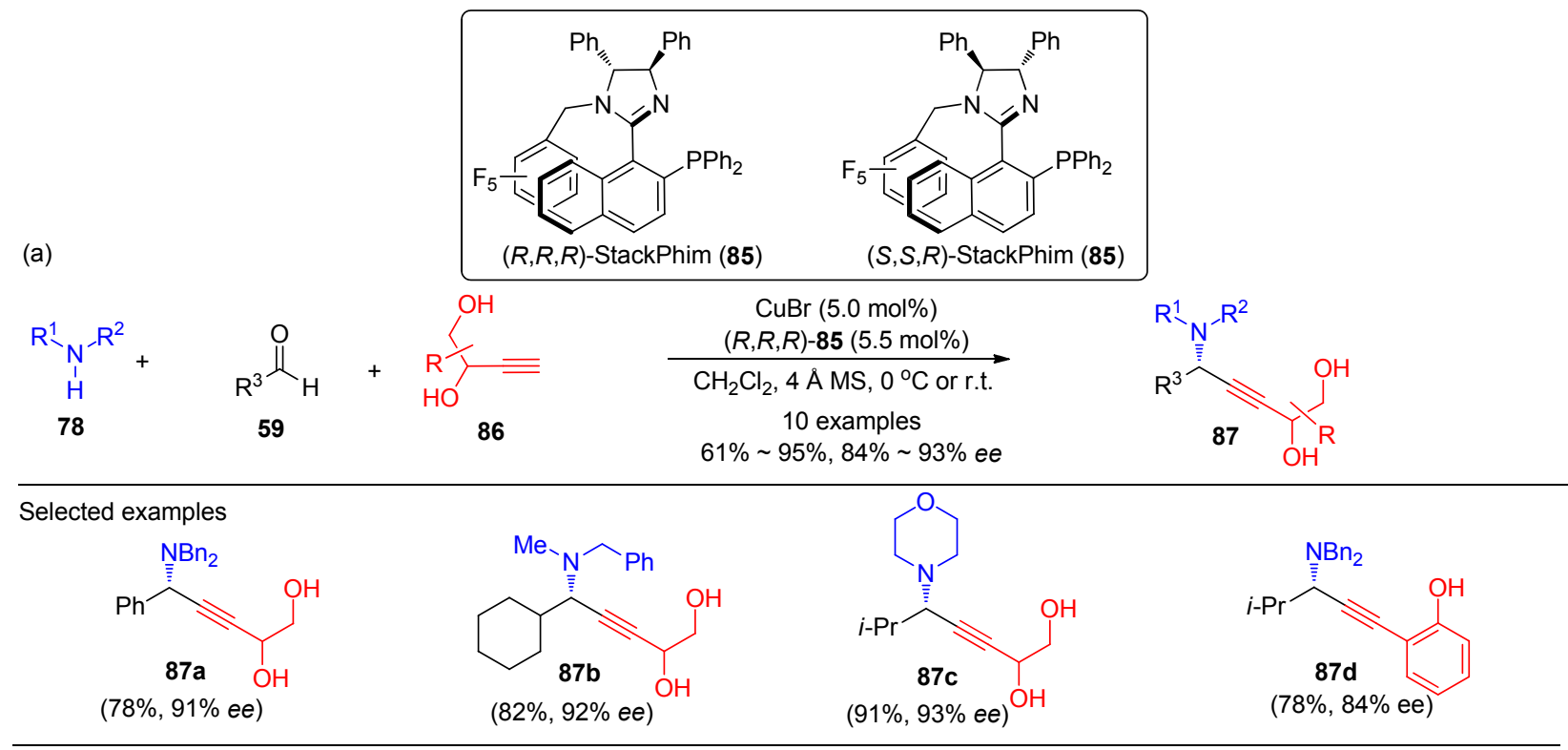

(b)

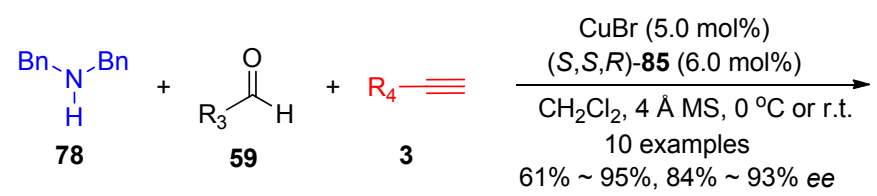

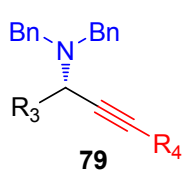

Selected examples
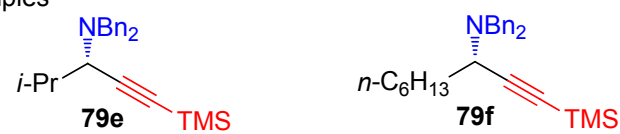

(89\%, 98\% ee)

$(86 \%, 94 \%$ ee $)$

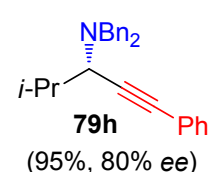

(c)

$\mathrm{Ar}-\mathrm{CHO}+\mathrm{N}_{59}^{\mathrm{H}}+\underset{\mathrm{HO}}{\mathbf{H}}=\frac{\begin{array}{c}\mathrm{CuBr}(1 \mathrm{~mol} \%) \\ \left(S, S, R_{\mathrm{a}}\right)-85(1.2 \mathrm{~mol} \%)\end{array}}{\begin{array}{c}\text { toluene, } 4 \AA \mathrm{MS}, \mathrm{r.t.}, 24 \mathrm{~h} \\ 22 \text { examples } \\ 53 \% \sim 99 \%, 88 \% \sim 99 \% \text { ee }\end{array}}$
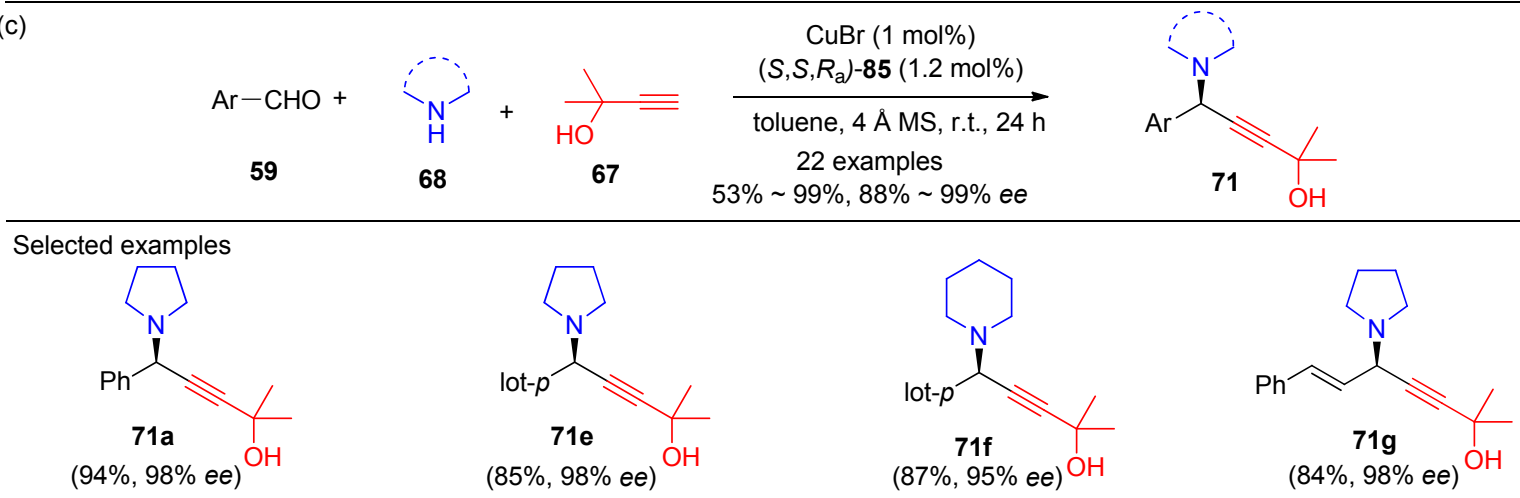

图式 31 手性 StackPhim 配体一铜络合物催化的不对称 $\mathrm{A}^{3}$ 反应

Scheme 31 Chiral stackPhim- $\mathrm{Cu}(\mathrm{I})$ complex catalyzed asymmetric $\mathrm{A}^{3}$ reaction 
底物和乙炔基三甲基硅烷展示了非常好的适用性，目标 炔丙胺产物均能够获得优秀的对映选择性; 但是, 芳香 醛和芳基末端炔底物反应结果则不太理想, 产物 79f 和 $79 \mathrm{~g}$ 仅能分别获得 $65 \%$ 和 $80 \%$ 的 ee 值. 最近, 他们研究 发现仅需将反应的末端炔换成 2-甲基-3-丁炔-2-醇 67, 同时使用环状二级胺替换二苄胺, 使用 $(S, S, R)$-StackPhim 85 亦能实现芳香醛参与的高对映选择性 $\mathrm{A}^{3}$ 反应 (Scheme 31, c) $)^{[38 c]}$. 即使将催化剂用量降低至 $1 \mathrm{~mol} \%$, 反应依旧能在 $24 \mathrm{~h}$ 内取得中等到优秀的产率和高达 99\%的对映选择性.

\subsubsection{Brønsted 酸-铜协同催化}

2013 年, Seidel 等 ${ }^{[39]}$ 设计合成了一种手性环己二胺 衍生的共轭碱稳定的 Brønsted 酸催化剂 89, 并将其用于 催化不对称 Povarov 反应. 鉴于二级胺参与的不对称 $\mathrm{A}^{3}$ 反应和 Povarov 反应都需要经历一个关键的亚胺正离子 中间体，他们设想能否将该类催化应用于实现二级胺参 与的不对称 $\mathrm{A}^{3}$ 反应. 经过系列探究, 他们最终发现使用 89 (3 mol\%)和 CuI (4 mol\%)协同催化, 可以高效高对映 选择性地实现四氢吡咯、芳香醛和末端炔的不对称 $\mathrm{A}^{3}$ 反应(Scheme 32) ${ }^{[40]}$. 该反应对脂肪醛和其他环状二级 胺也能适用, 但是产物的对映选择性会有所下降. 值得 注意的是, 相较于之前的反应中大多形成手性炔基铜络 合物来控制反应的立体选择性, 本反应则是通过对亚胺 中间体的活化来实现反应的立体选择性控制, 有效地拓 展了不对称 $\mathrm{A}^{3}$ 在反应的活化机制.

\section{2 酮亚胺的不对称炔基化反应}

酩亚胺的两边所连的均为非氢取代基, 使其整体的 空间位阻与醛亚胺相比更大, 因而发生加成反应活性较 醛亚胺而言有所下降; 两个取代基之间的位阻差异性变 得更小了，使得反应的立体选择性控制更为困难. 因此, 相较于醛亚胺的不对称炔基化反应而言, 酮亚胺的高对 映选择性炔基化反应更为困难，相关的报道也相对较 少. 但是, 化学家们通过在亚胺双键上引入强拉电子基 团或使用协同活化等策略, 为酮亚胺的亲核加成低活性 问题的解决提供了一系列行之有效的方案.

\section{1 非环状酮亚胺的不对称炔基化反应}

在 2011 年, 张新刚等 ${ }^{[41]}$ 利用 3,3-二(三甲基硅基)取 代的手性联䒺酚 91 作为手性配体, 二甲基锌作碱, 成功 实现了首例 $\alpha$-三氟甲基酮酸酯亚胺 90 的高对映选择性 炔基化反应来制备手性 $\alpha$-三氟甲基季碳氨基酸(Scheme 33). 由于三氟甲基和酯基两个拉电子基团的存在，使 得 $\alpha$-三氟甲基酮酸酯亚胺的活性较普通的酮亚胺而言 得到大幅度提升, 因此仅需要使用 $5 \mathrm{~mol} \%$ 的催化剂, 反 应就能够顺利进行, 芳基末端炔和烷基末端炔均能

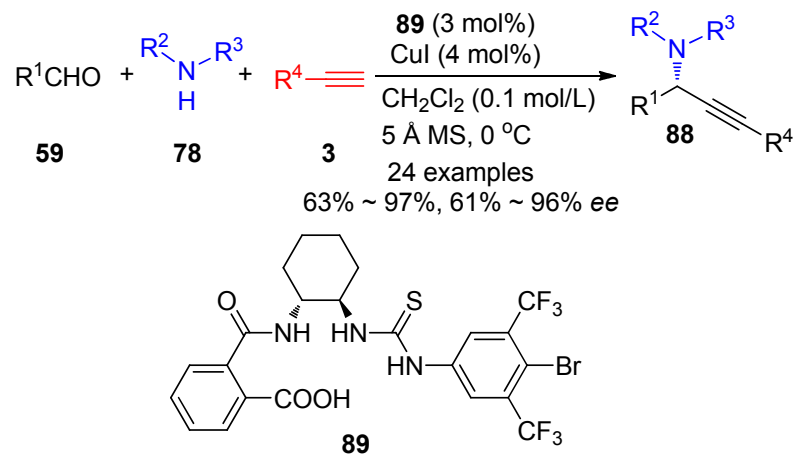

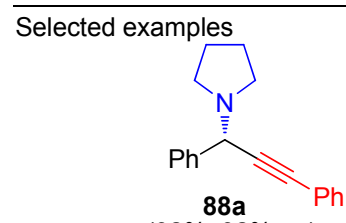

$(92 \%, 92 \%$ ee $)$

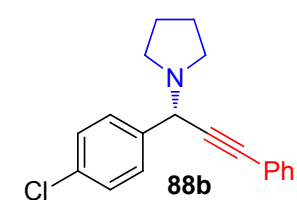

$(90 \%, 92 \%$ ee $)$

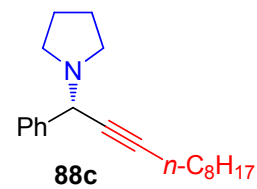

$(91 \%, 92 \%$ ee $)$
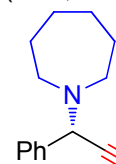

88d $\mathrm{Ph}$

$(80 \%, 88 \%$ ee $)$
图式 32 手性 Brønsted 酸-铜协同催化的不对称 $\mathrm{A}^{3}$ 反应 Scheme 32 Asymmetric $A^{3}$ reaction enabled by synergistic Brønsted acids and $\mathrm{Cu}(\mathrm{I})$ catalysis
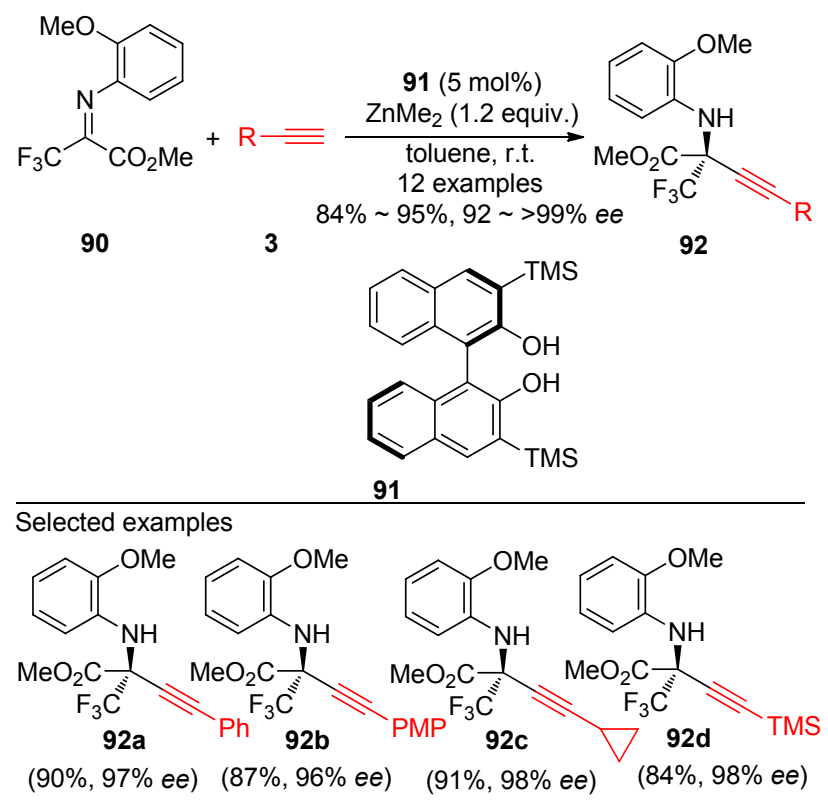

图式 33 首例 $\alpha$-三氟甲基亚胺酯的高对映选择性炔基化反应 Scheme 33 First highly enantioselective alkynylation of $\alpha$ ketoimine ester

兼容，并取得良好到优秀的产率和高达 $>99 \%$ 的 ee 值. 此外, 反应还可以克级规模进行而不影响对映选择性.

此后，该课题组 ${ }^{[42]}$ 通过在酮亚胺的氮原子上引入 更强拉电子基团，进一步实现了三氟甲基酮亚胺和芳基 酮酸酯亚胺的不对称炔基化反应(Scheme 34). 使用 3,3- 
二甲基取代的手性联萗酚 95 作为手性配体时, 三氟甲 基芳基酮亚胺 93 与一系列芳基和烷基末端炔 3 的不对 称加成反应能以高达 $98 \%$ 的产率和 $94 \%$ 的对映选择性 得到相应的手性 $\alpha$-三氟甲基炔丙胺产物 94 (Scheme 34,a); 芳基酮酸酯亚胺 97 的不对称炔基化反应则需要 使用 3,3-二(三氟甲磺酰基)取代的手性联萗酚 96 作为配 体, 相应的 $\alpha$-季碳氨基酸酯 98 可取得高达 $98 \%$ 的产率 和 $99 \%$ 的 $e e$ 值(Scheme 34,b).

(a)
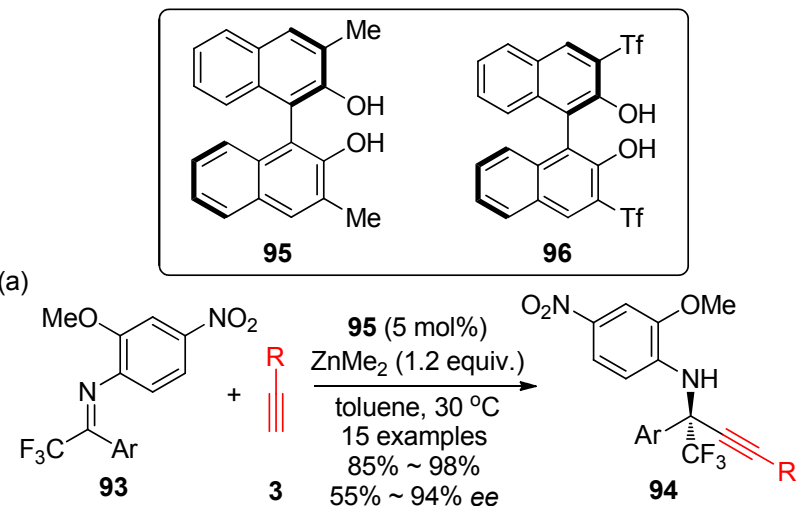

(b)

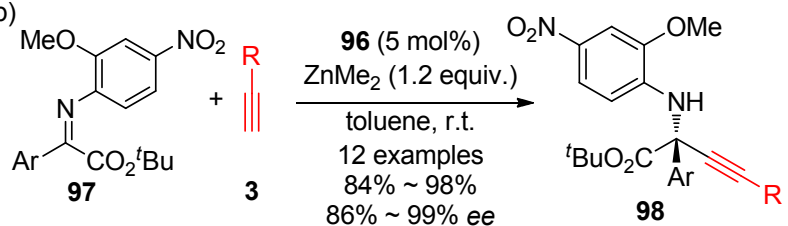

图式 $34 \mathrm{Zn}$-BINOL 催化的的高对映选择性炔基化反应

Scheme 34 Zn-BINOL catalyzed highly enantioselective alkynylations

同年, Ohshima 等 ${ }^{[43]}$ 利用他们发展的 Phebox-Rh 催 化剂实现了 $N-\mathrm{Cbz}$ 保护的 $\alpha$-三氟甲基酮酸酯亚胺的不 对称炔基化反应(Scheme 35). 经过配体篮选, 他们最终 发现使用对位硝基取代的 Phebox 时, 反应可取得最佳 的结果. 在 $2.5 \mathrm{~mol} \% \mathrm{Rh}(\mathrm{III})$ 络合物 99 的催化作用下, 芳基和杂芳基取代的末端炔对 $\mathbf{1 0 0}$ 的加成反应可在室温 下 $12 \mathrm{~h}$ 内进行完全并取得高达 95\%的 ee 值; 烷基末端 炔的反应则需要将温至 $0{ }^{\circ} \mathrm{C}$ 才能取得良好到优秀的对 映选择性.

此后, 该课题组 ${ }^{[44]}$ 对上述反应的机理进行了系统 研究发现, 反应真正的活性催化物种是 Phebox-Rh 和末 端炔经过酸碱作用得到的炔基 $\mathrm{Rh}$ 物种 $\mathrm{A}$; 在催化循环 中, 产物与催化剂络合物 $\mathbf{C}$ 质解生成最终产物的质子来 源于末端炔而非醋酸(Scheme 36). 基于上述机理探究, 他们设计了一种(三甲基硅基)乙炔基 $\mathrm{Rh}$ 催化剂 102. 对 比发现, 102 在催化烷基末端炔对 100 的不对称加成反 应中展示了明显高于 99 的催化活性. 接着, 该作者对 102 在酮亚胺的不对称炔基化反应中的适用性进行了探 究. 在芳基末端炔对 $N-\mathrm{Cbz}$ 保护的 $\alpha$-三氟甲基酮酸酯亚 胺 100 的不对称加成反应，仅需要使用 $0.5 \mathrm{~mol} \%$ 的 $\mathbf{1 0 2}$,

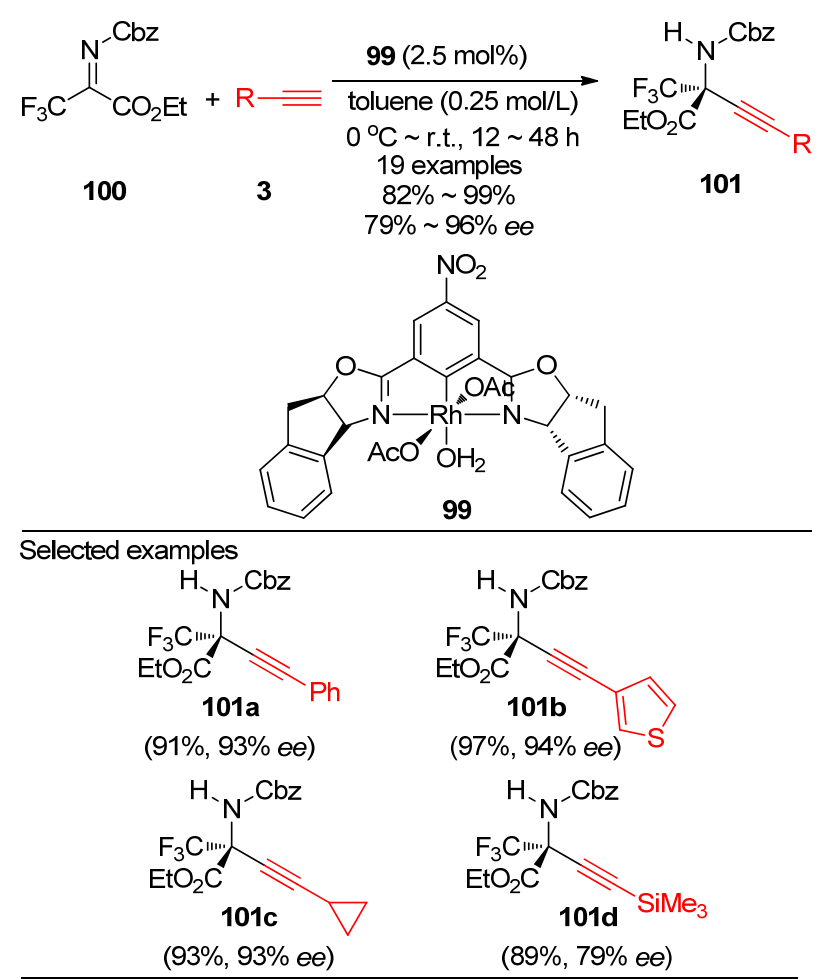

图式 35 Phebox-Rh 催化 $\alpha$-酮酸酯亚胺的高对映选择性炔基 化反应

Scheme 35 Phebox-Rh catalyzed highly enantioselective alkynylation of $\alpha$-ketoimine ester

反应即可在 $12 \mathrm{~h}$ 内进行完全并取得良好到优秀的产率 和 $e e$ 值(Scheme 36,a); 烷基末端炔的反应则需要降低 反应温度至 $0{ }^{\circ} \mathrm{C}$, 催化剂的用量升至 $2.5 \mathrm{~mol} \%$. 除了羧 酸酯亚胺，该反应还适用于磷酸酯亚胺的不对称炔基化 反应，相应的手性 $\alpha$-三氟甲基氨基磷酸酯 104 可取得 $80 \% \sim 93 \%$ 的 ee 值(Scheme 36, b).

与上述高活性的酮酸酯亚胺相比，简单酮衍生的亚 胺，由于缺乏了强拉电子基的活化作用，其亲核加成反 应的活性要低得多. 首例简单酩亚胺的直接不对称炔基 化反应直到 2013 年才由 Shibasaki 等 ${ }^{[45]}$ 报道(Scheme 37). 该作者在亚胺氮原子上引入较软的硫代二苯磷酰基保 护基，使得手性酮络合物在活化末端炔的同时也能对酮 亚胺进行活化; 这种对两个反应底物的双活化的策略是 反应取得成功的关键. 使用双膦配体 $(S, S)-\mathrm{Ph}-\mathrm{BPE}$ 衍生 的 $\mathrm{Cu}(\mathrm{I})$ 络合物作催化剂，一系列芳基和烷基末端炔均 能顺利与芳基酮亚胺反应，以 $68 \% \sim 94 \%$ 的产率和最高 $77 \%$ 的 $e e$ 值得到炔丙胺产物; 烷基酮亚胺也能适用于该 反应，但是产物的 $e e$ 值有所下降. 虽然反应的对映选择 性还有提升的空间，但是本反应发展的双活化策略对后 续低活性酮亚胺的不对称炔基化反应的发展具有重要 的启发意义.

以上述催化体系催化的不对称炔基化反应作为关 键步骤, 该课题组 ${ }^{[46]}$ 进一步实现了具有抗㾏活性的药 


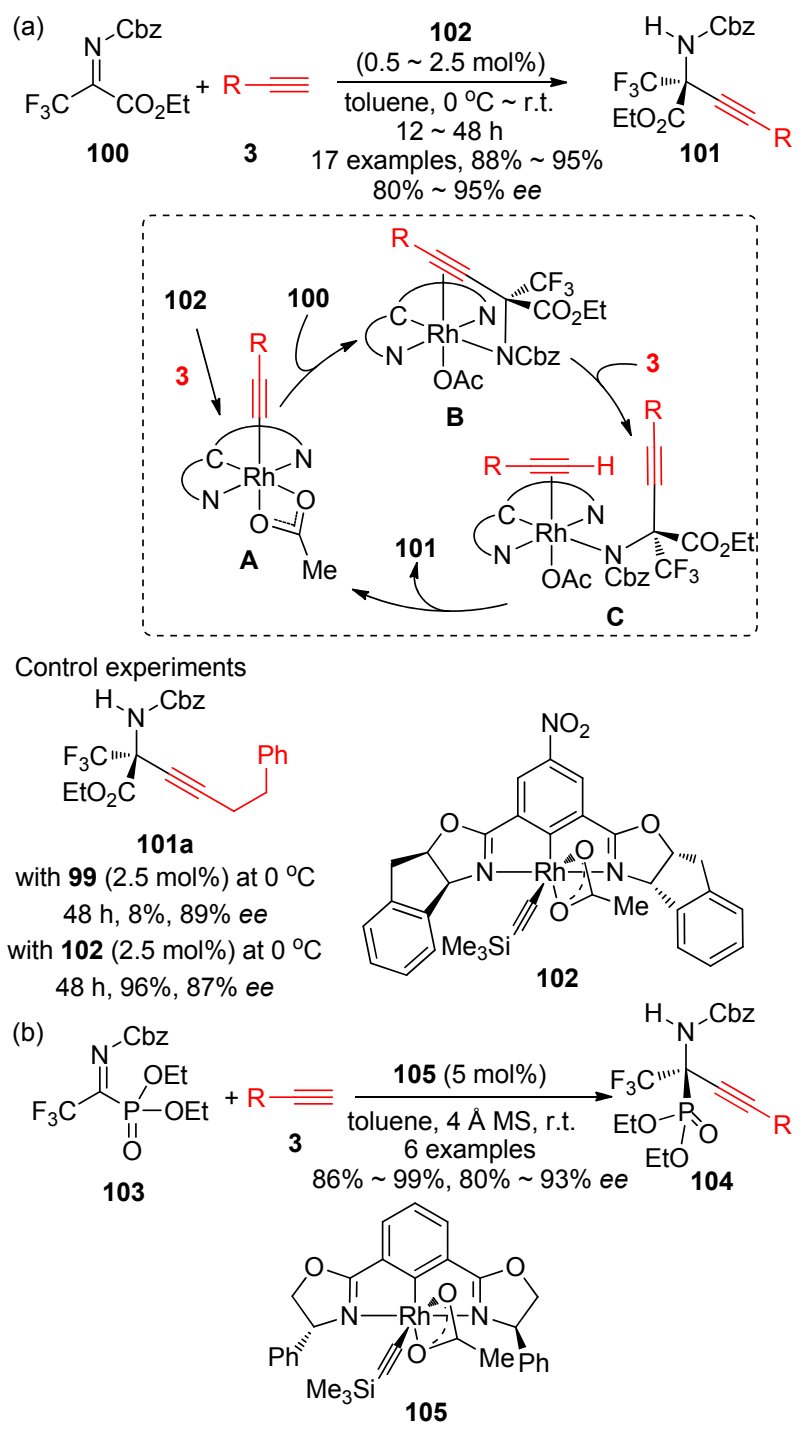

图式 36 炔基- $\mathrm{Rh}(\mathrm{III})$ 络合物催化的高对映选择性炔基化反应 Scheme 36 (Alkynyl)rhodium(III) complexes catalyzed highly enantioselective alkynylation

物分子 KAE069 的不对称全合成(Scheme 38). 从 $N$-硫代 二苯磷酰基保护的靛红亚胺 109 出发, 首先在 $(R, R)-\mathrm{Ph}-\mathrm{BPE}-\mathrm{Cu}(\mathrm{I})$ 络合物催化下与 $N$-Boc 保护的邻氨 基苯乙炔 110 发生加成反应并以 $97 \%$ 的产率和 $96 \%$ 的 $e e$ 值得到手性炔丙胺 111, 后者在经过保护基脱除和 $\mathrm{CuI}$ 催化的分子内胺氢化反应得到关键的 2-吲哚基 2-氨基 氧化吲哚中间体 112; 再经过多步后续转化即可实现 KAE069 的全合成.

此后, 刘小华课题组 ${ }^{[47]}$ 利用他们所发展的手性胍 作为配体, 系统考察了末端炔对靛红亚胺的不对称加成 反应(Scheme 39). 经过配体结构优化发现, 使用由 $L$-雷 米普利衍生的胍 114 与 $\mathrm{CuI}$ 的络合物作为催化剂时, 一 系列芳基和烷基末端炔 3 与靛红亚胺 113 的加成反应能 以 $50 \% \sim 95 \%$ 的产率以及 $86 \% \sim 96 \%$ 的 $e e$ 值得到相应的
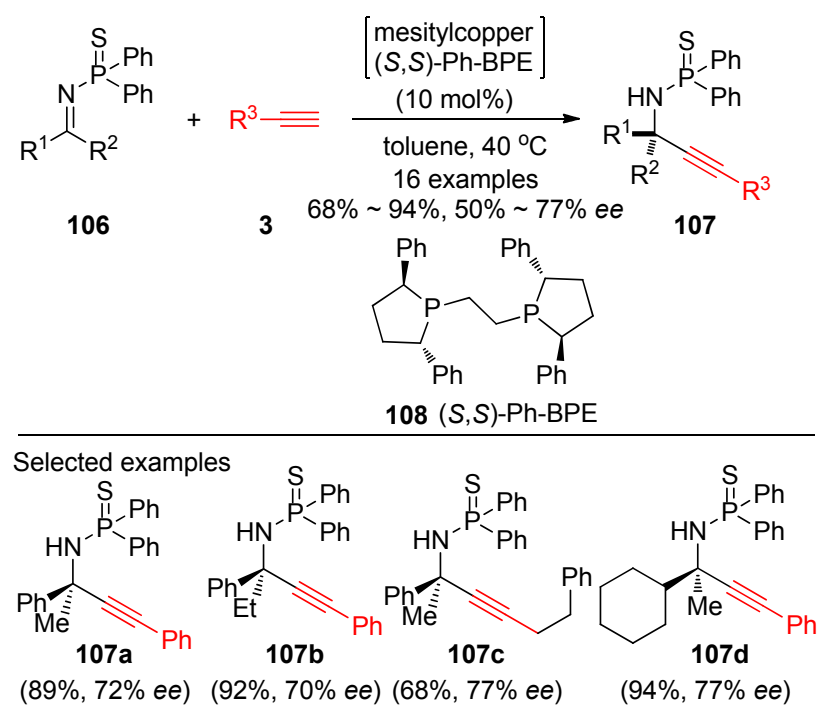

图式 37 非环状简单酮亚胺的不对称炔基化反应 Scheme 37 Catalytic asymmetric alkynylation of acyclic ketoimines derived from simple ketones

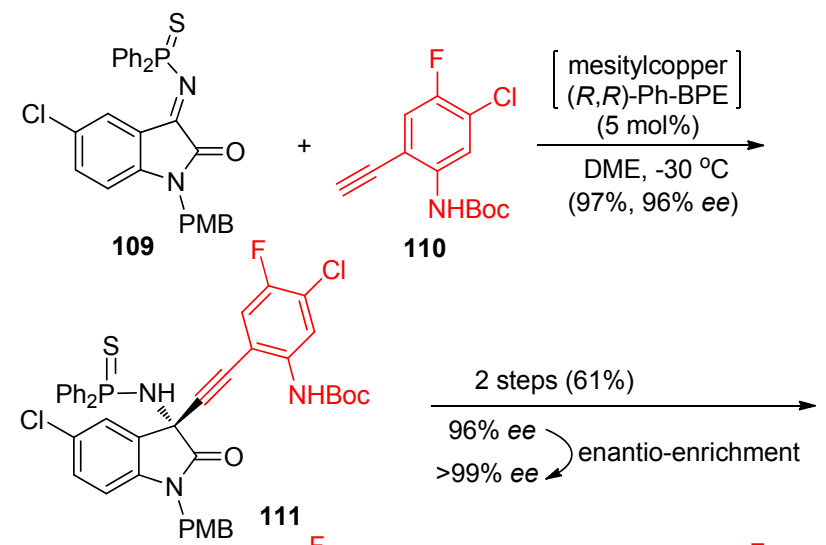<smiles>[R16]O[R16](=O)O[Na]</smiles>

图式 38 药物分子 KAE069 的不对称全合成

Scheme 38 Total synthesis of drug molecule KAE069

手性 3-炔丙基-3-氨基氧化吲哚 115. 经过初步的机理研 究，作者认为手性胍配体不仅能作碱促进活性炔基铜物 种的生成, 手性胍 114 瞳氢所生成的胍盐还能通过氢键 或者配体对靛红亚胺进行活化.

\section{2 环状酮亚胺的不对称炔基化反应}

在成功实现了末端炔对环状偶氮甲碱亚胺的不对 称加成反应的基础上(Scheme 8), Maruoka 等 ${ }^{[10]}$ 进一步 使用 PyBOX-Cu(I) 络合物和轴手性 Brønsted 酸协同催化 剂实现了 1-烷基环状偶氮甲碱亚胺 116 的不对称炔基化 

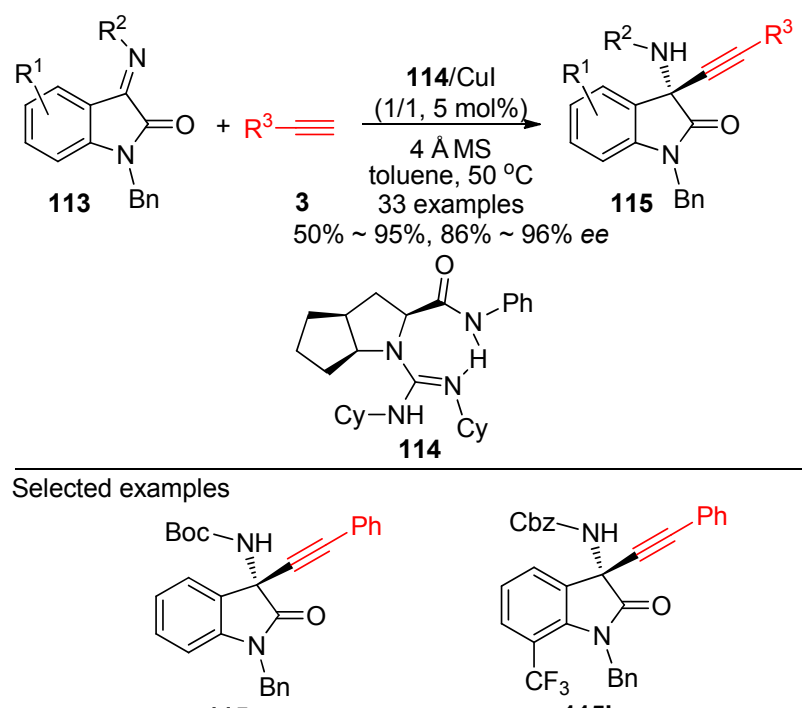

$115 \mathrm{a}$

$(83 \%, 95 \%$ ee)

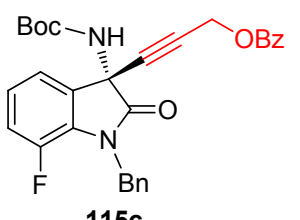

$115 \mathrm{c}$

$(50 \%, 95 \%$ ee $)$

图式 39 靛红亚胺的不对称炔基化反应

Scheme 39 Asymmetric alkynylation of isatin-derived ketimines

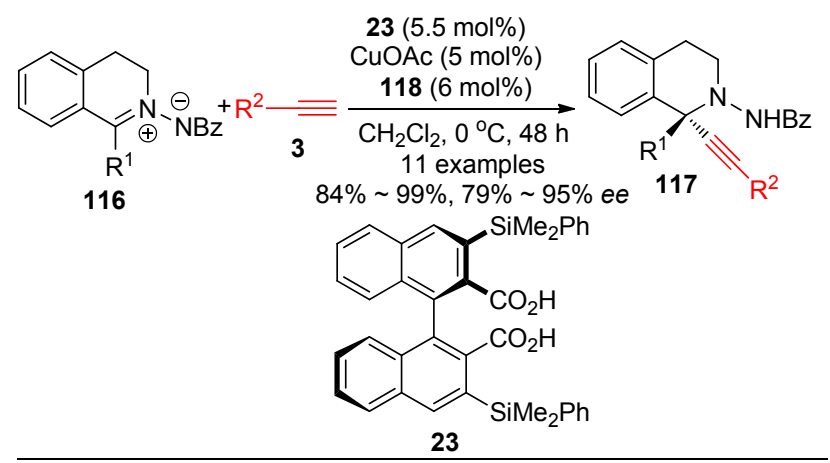

Selected examples

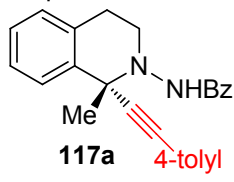

$(97 \%, 93 \%$ ee $)$

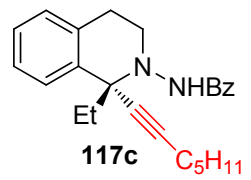

(84\%, 90\% ee)

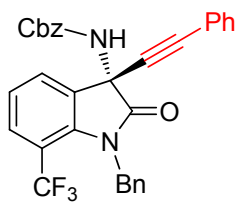

$115 b$

$(85 \%, 91 \%$ ee $)$

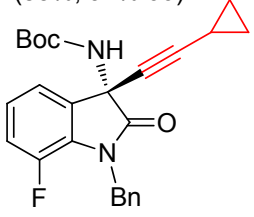

$115 d$

$(69 \%, 94 \%$ ee $)$
加入可以显著提高反应的对映选择性. 在 $5 \mathrm{~mol} \%$ 的 $\mathrm{Cu}(\mathrm{I})$ 络合物和 $6 \mathrm{~mol} \%$ 的 3,3-二(二甲基苯基硅基)联芸骨 架衍生的手性二羧酸 118 的催化下, 芳基和烷基末端炔 对 116 的加成反应可以高达 99\%的产率和 95\%的 ee 值 生成 1-烷基-1-炔丙基四氢异喹啉衍生物 117.

Watson 等 ${ }^{[48]}$ 通过将环状酮亚胺现场活化成亚胺正 离子, 实现了末端炔对其的不对称炔基化反应(Scheme 41). 他们使用 $\mathrm{ClCO}_{2} \mathrm{Me}$ 作为活化试剂, DIPEA 作碱, $\alpha, \alpha$-二芳基环状酮亚胺首先发生酰基化反应生成亚胺正 离子 $\mathbf{A}$, 后者与 PyBOX 配体衍生的炔基铜发生加成反 应得到 1-芳基-1-炔丙基四氢异喹啉衍生物 120. 在最佳 条件下，芳基末端炔的反应可取得最高 $96 \%$ 的 $e e$ 值，但 是烷基末端炔底物的反应仅能取得中等的对映选择性; 使用大位阻的三苯基硅基乙炔时，反应可取得最佳的结 果(120b).

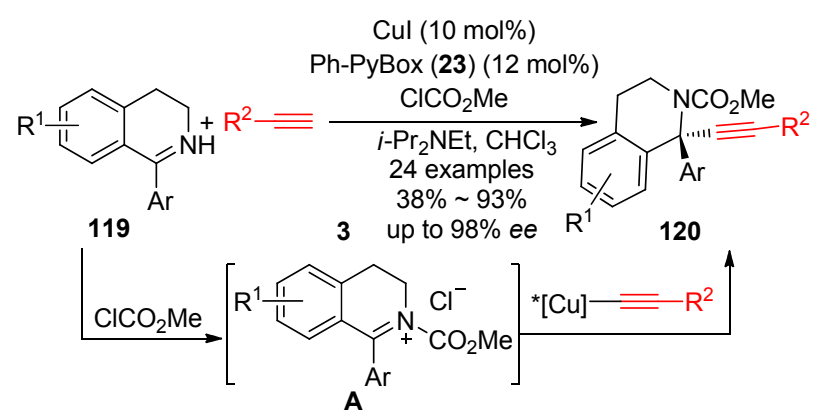

Selected examples

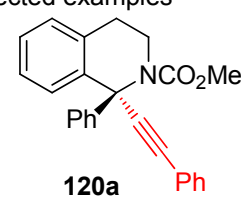

$(77 \%, 91 \%$ ee $)$

$\mathrm{Br}$<smiles>COC(=O)N1CCc2cc(Br)ccc2[C@]1(C#CC(=O)O)c1ccccc1</smiles>

$(92 \%, 91 \%$ ee $)$

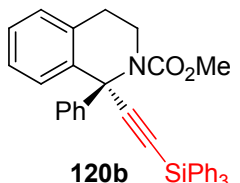

$(76 \%, 98 \%$ ee $)$

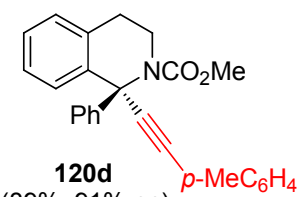

图式 $41 \alpha, \alpha$-二芳基环状酮亚胺的不对称炔基化反应

Scheme 41 Cu-catalyzed enantioselective alkynylation of $\alpha, \alpha$-diaryl ketimines

马军安课题组 ${ }^{[49]}$ 系统地研究了 $N$-酰基环状三氟甲 基酮亚胺 121 的不对称炔基化反应(Scheme 42). 早在 2012 年, 他们使用氯霉素的胺衍生物 $\mathbf{1 2 3}$ 作为手性配 体, 实现了一系列末端二炔 8 对 121 的不对称加成反应 并以高达 94\%的 $e e$ 值得到了相应的二炔基化产物 122 (Scheme 42,a). 值得一提的是，该作者也尝试了使用 PyBOX、 $N$-PINAP 等配体衍生的 $\mathrm{Cu}(\mathrm{I})$ 络合物来催化上 述反应，但是反应结果均不理想. 此后，他们进一步发

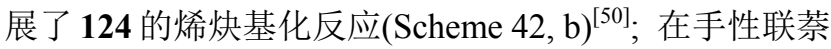

图式 40 1-烷基环状偶氮甲碱亚胺的不对称炔基化反应 Scheme 40 Catalytic asymmetric alkynylation of 1-alkyl C,Ncyclic azomethine imines

反应(Scheme 40). 对照实验表明, 轴手性 Brønsted 酸的
酚配体 126 与 $\mathrm{ZnMe}_{2}$ 的络合物催化下, 相应的炔基化产 
物可取得中等到优秀的对映选择性, 芳基和烷基烯炔都 能兼容.

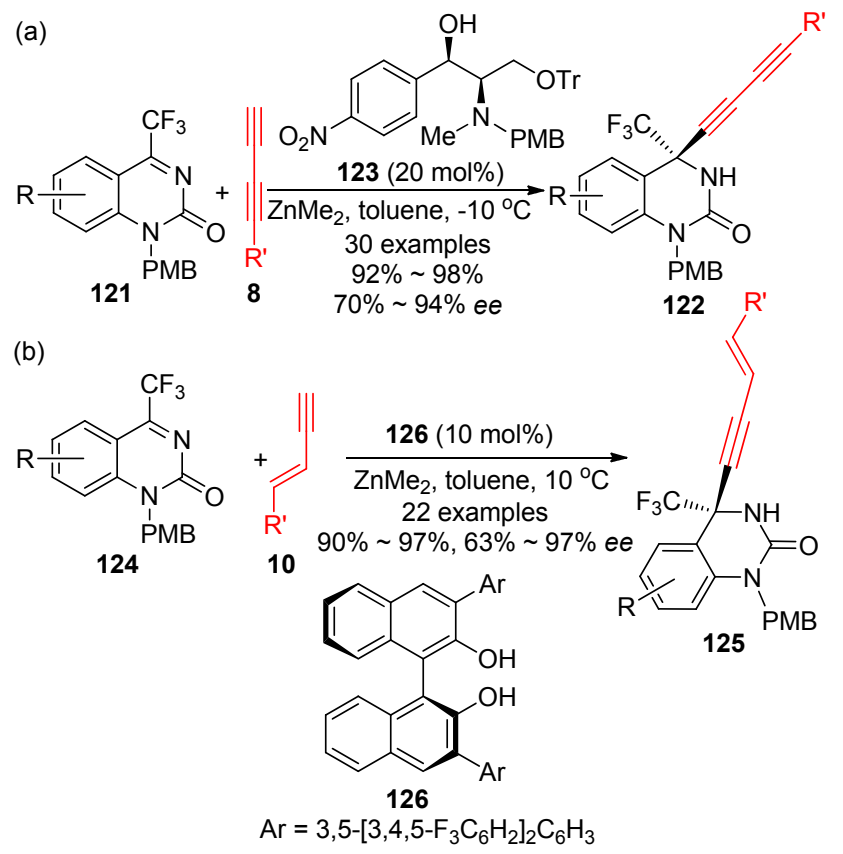

图式 $42 N$-酰基环状三氟甲基酮亚胺的不对称炔基化反应

Scheme 42 Catalytic asymmetric alkynylation of cyclic $N$-acyl trifluoromethyl ketimines

2016 年, Ohshima 等 ${ }^{[44]}$ 利用他们发展的 Phebox 衍生 的(三甲基硅基)乙炔基 Rh 催化剂 129 实现了首例环状 $N$-磺酰基酮酸酯亚胺 127 的不对称炔基化反应(Scheme 43). 在 $5 \mathrm{~mol} \%$ 的 129 的存在下, 芳基和烷基末端炔对 127 的加成反应, 在 $70{ }^{\circ} \mathrm{C}$ 下可取得优秀的产率和 $78 \% \sim 87 \%$ 的 $e e$ 值. 此后在 2017 年, 张万斌和贾义霞课 题组同时报道了他们在环状酮酸酯亚胺 127 不对称炔基 化反应中的研究成果. 张万斌等 ${ }^{[51]}$ 使用偕二烷基取代 的手性双啞唑啉 130 衍生的 $\mathrm{Cu}(\mathrm{II})$ 络合物作为催化剂, 外加 LiOAc 作为碱, 实现了芳基末端炔对取代环状亚胺 127 的加成反应并以高达 $97 \%$ 的产率和 $98 \%$ 的 $e e$ 值得到 环状炔丙胺产物. 此外, 该催化体系亦能催化六元环状 酮亚胺的不对称炔基化反应并取得中等到良好的对映 选择性。

贾义霞课题组 ${ }^{[52]}$ 研究发现, 在 $(R)$-DTBM-Segphos 131 与 $\mathrm{Ni}\left(\mathrm{ClO}_{4}\right)_{2} \cdot 6 \mathrm{H}_{2} \mathrm{O}$ 络合物的催化下, $N$-磺酰基酮酸 酯亚胺 127 与芳基末端炔的不对称反应在 $50{ }^{\circ} \mathrm{C}$ 下可取 得最高 $83 \%$ 的产率和 $94 \%$ 的对映选择性. 此外, 该作者 也在上述条件下尝试了烷基末端炔底物, 发现反应并不 能进行. 经过后续考察发现, 在反应体系中添加 20 $\mathrm{mol} \%$ 的 $\mathrm{Ag}_{2} \mathrm{CO}_{3}$ 作为烷基炔的活化剂, 即可实现其对 127 的加成反应并取得良好到优秀的对映选择性, 但产 率依旧不理想. 经过对照实验和理论计算, 该作者认为 本反应更倾向于通过 Friedel-Crafts 类型的机理进行的,
而非经典的通过形成手性炔基金属物种机理.

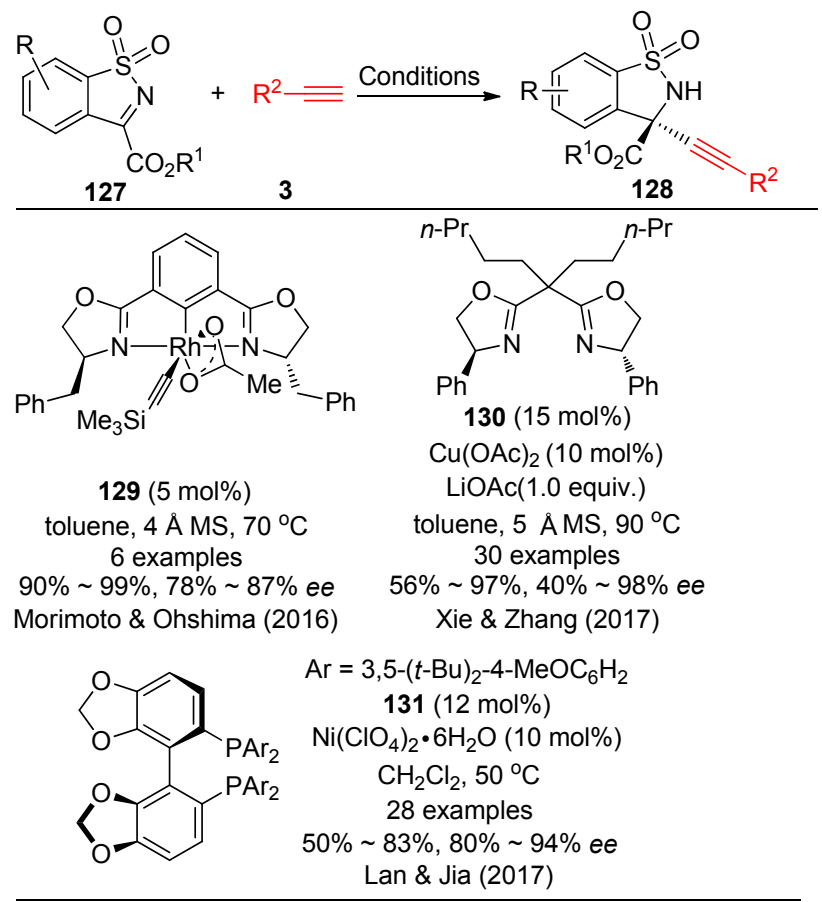

图式 $43 N$-磺酰基酮酸酯亚胺的不对称炔基化反应 Scheme 43 Asymmetric alkynylation of cyclic $N$-sulfonyl ketimines

\section{3 总结与展望}

在过去的十年中, 醛亚胺的不对称炔基化反应已经 从最初需要使用预先制备的亚胺发展成为可以使用更 为稳定的亚胺前体化合物作为起始原料, 反应在操作的 简便性和起源原料来源的广泛性上都得到了较大的发 展. 相较于醛亚胺的广泛研究, 酮亚胺的不对称炔基化 反应则相对报道较少, 现有的反应大多集中在使用高活 性的底物。

尽管亚胺及其类似物的不对称炔基化反应在近十 年得到了快速发展, 但这一领域的研究仍然还有需要进 一步探索的问题: (1)目前为止，环状醛亚胺的不对称炔 基化反应在不对称全合成已经得到了较为广泛的应用， 但是非环状醛亚胺不对称炔基化反应的应用实例却较 少报道; (2)基于不对称亚胺炔基化的串联反应已经在合 成氮杂环状化合物中展示了其巨大的潜力，但是相关的 报道仍然比较有限; (3)简单酮衍生亚胺的不对称炔基化 反应仅有一例报道，反应的活性和对映选择性均还有较 大的提升空间，应该成为今后发展的一个重点领域; Shibasaki 等所使用的双活化策略为解决简单亚胺的不 对称炔基化反应的活性问题提供了很好的思路; (4)酮亚 胺不对称炔基化反应的底物类型依然比较有限, 发展更 多结构多样的酮亚胺的不对称炔基化反应也是未来的 一个发展方向; (5)发展廉价的催化体系和探究相关反应 
的实用性也是值得关注的发展方向. 鉴于亚胺不对称炔 基化反应的巨大应用潜力，通过新活化策略和催化体系 的开发，该反应在未来依然会是化学家们关注的热点， 更多相关反应在不对称全合成的应用实例也值得期待.

\section{References}

[1] Lauder, K.; Toscani, A.; Scalacci, N.; Castagnolo, D. Chem. Rev. 2017, 117, 14091 .

[2] (a) Lu, G.; Li, Y.-M.; Li, X.-S.; Chan, A. S. C. Coord. Chem. Rev. 2005, 249, 1736.

(b) Blay, G.; Monleón, A.; Pedro, J. R. Curr. Org. Chem. 2009, 13, 1498.

(c) Bian, Q.; Zhong, J.; Hou, S.; Wang, M. Chin. J. Org. Chem. 2010, 30, 1261 (in Chinese).

(边庆花, 钟江春, 侯士聪, 王敏, 有机化学, 2010, 30, 1261.)

(d) Cheng, M.; Li B.-G. Chin. Synth. Chem. 2012, 20, 1 (in Chinese).

(成明，李伯刚，合成化学, 2012, 20, 1.)

(e) Bisai, V.; Singh, V. K. Tetrahedron Lett. 2016, 57, 4771.

[3] Yan, W.; Li, P.; Feng, J.; Wang, D.; Zhu, S.; Jiang, X.; Wang, R. Tetrahedron: Asymmetry 2010, 21, 2037.

[4] Blay, G.; Ceballos, E.; Monleon, A.; Pedro, J. R. Tetrahedron 2012, $68,2128$.

[5] (a) Liu, T.-L.; Zhang, H.-X.; Zheng, Y.; Yao, Q.; Ma, J.-A. Chem. Commun. 2012, 48, 12234.

(b) Yang, Z.-Y.; Liu, T.-L.; Zheng, Y.; Li, S.; Ma, J.-A. Eur. J. Org. Chem. 2015, 3905.

[6] Blay, G.; Brines, A.; Monlen, A.; Pedro, J. R. Chem.-Eur. J. 2012, 18,2440 .

[7] Xie, Z.; Liu, X.; Liu, L. Org. Lett. 2016, 18, 2982.

[8] Luzung, M. R.; Dixon, D. D.; Ortiz, A.; Guerrero, C. A.; Ayers, S.; Ho, J.; Schmidt, M. A.; Strotman, N. A.; Eastgate, M. D. J. Org. Chem. 2017, 82, 10715 .

[9] (a) Campbell, M. J.; Toste, F. D. Chem. Sci. 2011, 2, 1369. (b) Ranjan, A.; Mandal, A.; Yerande, S. G.; Dethe, D. H. Chem. Commun. 2015, 51, 14215.

[10] Hashimoto, T.; Omote, M.; Maruoka, K. Angew. Chem., Int. Ed. 2011, 50, 8952.

[11] Pappoppula, M.; Cardoso, F. S. P.; Garrett, B.O.; Aaron, A. Angew. Chem., Int. Ed. 2015, 54, 15202.

[12] Kou, X.; Zhao, Q.; Guan, Z.-H. Org. Chem. Front. 2020, 7, 838.

[13] Ren, Y.-Y.; Wang, Y.-Q.; Liu, S. J. Org. Chem. 2014, 79, 11759.

[14] Munck, L. D.; Monleón, A.; Vila, C.; Muñoz, M. C.; Pedro, J. R. Org. Biomol. Chem. 2015, 13, 7393.

[15] Munck, L. D.; Monleón, A.; Vila, C.; Pedro, J. R. Adv. Synth. Catal. 2017, 359, 1582.

[16] Yu, J.; Li, Z.; Jia, K.; Jiang, Z.; Liu, M.; Su, W. Tetrahedron Lett. 2013, 54, 2006.

[17] Sun, S.; Li, C.; Floreancig, P. E.; Lou, H.; Liu, L. Org. Lett. 2015, 17, 1684.

[18] Sun, S.; Liu, L. Synthesis 2016, 48, 2627.

[19] Perepichka, I.; Kundu, S.; Hearne, Z.; Li, C.-J. Org. Biomol. Chem. 2015, 13, 447 .

[20] Huang, T.; Liu, X.; Lang, J.; Xu, J.; Lin, L.; Feng, X. ACS Catal. 2017, 7, 5654

[21] (a) Wei, C.; Li, C.-J. J. Am. Chem. Soc. 2002, 124, 5638.

(b) Wei, C.; Mague, J. T.; Li, C.-J. Proc. Natl. Acad. Sci. U. S. A. 2004, 101, 5749 .

Selected reviews:

(c) Peshkov, V. A.; Pereshivko, O. P.; Van der Eycken, E. V. Chem. Soc. Rev. 2012, 41, 3790.

(d) Rokade, B. V.; Barker, J.; Guiry, P. J. Chem. Soc. Rev. 2019, 48, 4766 .

(e) Mo, J.-N.; Su, J.; Zhao, J. Molecules 2019, 24, 1216. (f) Jesin, I.; Nandi, G. C. Eur. J. Org. Chem. 2019, 2704

[22] Bisai, V.; Suneja, A.; Singh, V. K. Angew. Chem., Int. Ed. 2014, 53, 10737.

[23] Das, B. G.; Shah, S.; Singh, V. K. Org. Lett. 2019, 21, 4981.

[24] Dhanasekaran, S.; Kannaujiya, V. K.; Biswas, R. G.; Singh, V. K. J. Org. Chem. 2019, 84, 3275.

[25] Li, Z.; Jiang, Z.; Su, W. Green Chem. 2015, 17, 2330.

[26] Gao, X.-T.; Gan, C.-C.; Liu, S.-Y.; Zhou, F.; Wu, H.-H.; Zhou, J. ACS Catal. 2017, 7, 8588.

[27] (a) Nakamura, S.; Hyodo, K.; Nakamura, Y.; Shibata, N.; Toru, T. Adv. Synth. Catal. 2008, 350, 1443. (b) Liu, H.; Du, D.-M. Adv. Synth. Catal. 2009, 351, 489.

[28] Nakamura, S.; Ohara, M.; Nakamura, Y.; Shibata, N.; Toru, T. Chem.-Eur. J. 2010, 16, 2360.

[29] Ohara, M.; Hara, Y.; Ohnuki, T.; Nakamura, S. Chem.-Eur. J. 2014 20,8848 .

[30] Knöpfel, T. E.; Aschwanden, P.; Ichikawa, T.; Watanabe, T.; Carreira, E. M. Angew. Chem., Int. Ed. 2004, 43, 5971.

[31] Huang, X.; Ma, S. Acc. Chem. Res. 2019, 52, 1301.

[32] (a) Ye, J.; Li, S.; Chen, B.; Fan, W.; Kuang, J.; Liu, J.; Liu, Y.; Miao, B.; Wan, B.; Wang, Y.; Xie, X.; Yu, Q.; Yuan, W.; Ma, S. Org. Lett. 2012, 14, 1346.

(b) Liu, Q.; Cao, T.; Han, Y.; Jiang, X.; Tang, Y.; Zhai, Y.; Ma, S. Synlett 2019, 30, 477.

[33] Fan, W.; Ma, S. Chem. Commun. 2013, 49, 10175.

[34] Fan, W.; Yuan, W.; Ma, S. Nat. Commun. 2014, 5, 1 .

[35] (a) Lin, W.; Cao, T.; Fan, W.; Han, Y.; Kuang, J.; Luo, H.; Miao, B.; Tang, X.; Yu, Q.; Yuan, W.; Zhang, J.; Zhu, C.; Ma, S. Angew. Chem., Int. Ed. 2014, 53, 277.

(b) Lin, W.; Ma, S. Org. Chem. Front. 2014, 1, 338.

(c) Lin, W.; Ma, S. Org. Chem. Front. 2017, 4, 958.

[36] Zhou, S.; Tong, R. Org. Lett. 2017, 19, 1594.

[37] (a) Cardoso, F. S. P.; Abboud, K. A.; Aponick, A. J. Am. Chem. Soc. 2013, 135, 14548.

(b) Paioti, P. H. S.; Abboud, K. A.; Aponick, A. J. Am. Chem. Soc 2016, 138, 2150.

[38] (a) Paioti, P. H. S.; Abboud, K. A.; Aponick, A. ACS Catal. 2017, 7 2133.

(b) Rokade, B. V.; Guiry, P. J. ACS Catal. 2017, 7, 2334

(c) Rokade, B. V.; Guiry, P. J. J. Org. Chem. 2019, 84, 5763.

[39] (a) Min, C.; Mittal, N.; Sun, D. X.; Seidel, D. Angew. Chem., Int. Ed. 2013, 52, 14084.

(b) Mittal, N.; Sun, D. X.; Seidel, D. Org. Lett. 2014, 16, 1012.

[40] Zhao, C.; Seidel, D. J. Am. Chem. Soc. 2015, 137, 4650.

[41] Huang, G.; Yang, J.; Zhang, X. Chem. Commun. 2011, 47, 5587.

[42] Huang, G.; Yin, Z.; Zhang, X. Chem.-Eur. J. 2013, 19, 11992.

[43] Morisaki, K.; Sawa, M.; Nomaguchi, J.-Y.; Morimoto, H.; Takeuchi, Y.; Mashima, K.; Ohshima, T. Chem.-Eur. J. 2013, 19, 8417.

[44] Morisaki, K.; Sawa, M.; Yonesaki, R.; Morimoto, H.; Mashima, K.; Ohshima, T. J. Am. Chem. Soc. 2016, 138, 6194.

[45] Yin, L.; Otsuka, Y.; Takada, H.; Mouri, S.; Yazaki, R.; Kumagai, N.; Shibasaki, M. Org. Lett. 2013, 698.

[46] Takada, H.; Kumagai, N.; Shibasaki, M. Org. Lett. 2015, 17, 4762.

[47] Chen, Q.; Xie, L.; Li, Z.; Tang, Y.; Zhao, P.; Lin, L.; Feng, X.; Liu, X. Chem. Commun. 2018, 54, 678.

[48] Dasgupta, S.; Liu, J.; Shoffler, C. A.; Yap, G. P. A.; Watson, M. P. Org. Lett. 2016, 18, 6006.

[49] Zhang, F.-G.; Ma, H.; Nie, J.; Zheng, Y.; Gao, Q.; Ma, J.-A. Adv. Synth. Catal. 2012, 354, 1422.

[50] Zhang, Y.; Nie, J.; Zhang, F.-G.; Ma, J.-A. J. Fluorine Chem. 2018, 208,1 .

[51] Ling, Z.; Singh, S.; Xie, F.; Wu, L.; Zhang, W. Chem. Commun. 2017, 53, 5364.

[52] Liu, R.-R.; Zhu, L.; Hu, J.-P.; Lu, C.-J.; Gao, J.-R.; Lan, Y.; Jia, Y.-X. Chem. Commun. 2017, 53, 5890 . 